Provided for non-commercial research and education use. Not for reproduction, distribution or commercial use.

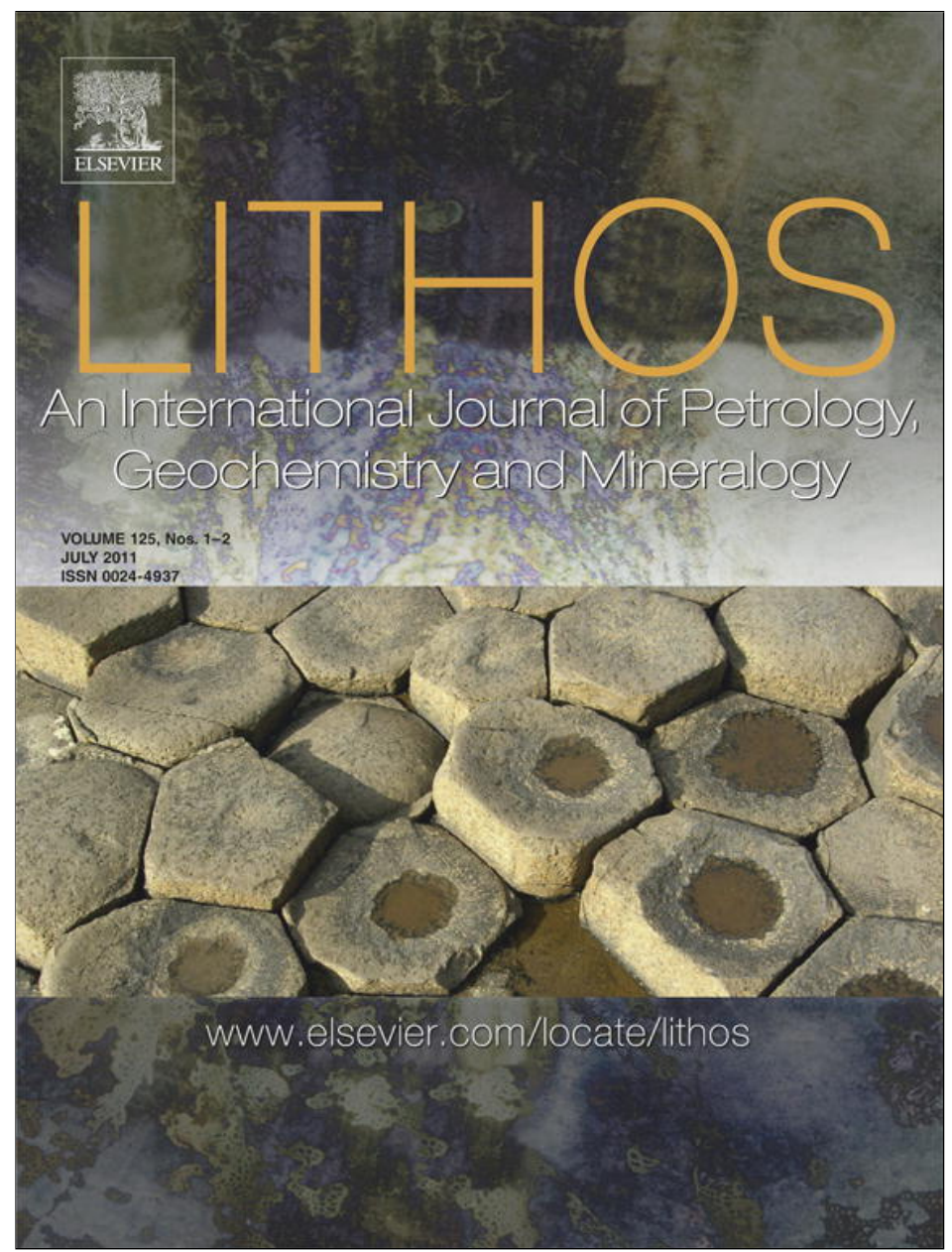

This article appeared in a journal published by Elsevier. The attached copy is furnished to the author for internal non-commercial research and education use, including for instruction at the authors institution and sharing with colleagues.

Other uses, including reproduction and distribution, or selling or licensing copies, or posting to personal, institutional or third party websites are prohibited.

In most cases authors are permitted to post their version of the article (e.g. in Word or Tex form) to their personal website or institutional repository. Authors requiring further information regarding Elsevier's archiving and manuscript policies are encouraged to visit:

http://www.elsevier.com/copyright 


\title{
Garnet-bearing ultramafic rocks from the Dominican Republic: Fossil mantle plume fragments in an ultra high pressure oceanic complex?
}

\author{
Esteban Gazel ${ }^{\mathrm{a}, *}$, Richard N. Abbott Jr. ${ }^{\mathrm{b}}$, Grenville Draper ${ }^{\mathrm{c}}$ \\ a Lamont-Doherty Earth Observatory, Columbia University, Palisades, NY 10964, USA \\ b Department of Geology, Appalachian State University, Boone, NC 28608, USA \\ c Department of Earth and Environment, Florida International University, FL 33199, USA
}

\section{A R T I C L E I N F O}

\section{Article history:}

Received 23 December 2010

Accepted 23 February 2011

Available online 5 March 2011

\section{Keywords:}

Garnet

Ultramafic rocks

Rare earth elements

Ultra high pressure

Mantle plume

\begin{abstract}
A B S T R A C T
Ultra high pressure (UHP) garnet-bearing ultramafic rocks from the Dominican Republic may represent the only known example where such rocks were exhumed at an ocean-ocean convergent plate boundary, and where the protolith crystallized from a UHP magma $\left(>3.2 \mathrm{GPa},>1500^{\circ} \mathrm{C}\right)$. This study focuses on the petrology and geochemistry of one of the ultramafic lithologies, the pegmatitic garnet-clinopyroxenite (garnet + clinopyroxene + spinel + corundum + hornblende). Three distinct types of garnet were recognized: Type-1 garnet (low Ca, high $\mathrm{Mg}$ ) is interpreted as near magmatic ( $\mathrm{P}>3.2 \mathrm{GPa},>1500{ }^{\circ} \mathrm{C}$ ). Type- $1^{\prime}$ garnet (high $\mathrm{Ca}$, low $\mathrm{Mg}$ ) is interpreted as having formed approximately isochemically from magmatic high- $\mathrm{Al}$ clinopyroxene. Type- 2 garnet (intermediate $\mathrm{Ca}$, high $\mathrm{Mg}$, and low $\mathrm{Fe}+\mathrm{Mn}$ ) formed together with hornblende as a result of late, low-pressure retrograde hydration. Clinopyroxene is close to diopside-hedenbergite (Mg\# 88) and metasomatized by arc-related fluids. Spinel and corundum occur as microinclusions in type- 1 and type-1' garnets in the only reported natural occurrence of coexisting garnet + spinel + corundum, indicative of very high pressure. Chondrite-normalized REEs (rare earth elements) of the garnets show humped or weakly sinusoidal patterns, typically associated with garnet inclusions in diamond and garnet in kimberlite that crystallized at UHP conditions. These humped to weakly sinusoidal REE patterns developed as the result of interaction with a light REE-enriched metasomatic fluid. Partitioning of REEs between type- $\mathbf{1}^{\prime}$ and type- 1 garnets is consistent with the former having inherited its REEs from a high-Al clinopyroxene predecessor. The partitioning preserves a record of near-solidus temperatures $\left(\sim 1475^{\circ} \mathrm{C}\right)$. Petrology and phase relationships independently suggest near-solidus conditions $>1500{ }^{\circ} \mathrm{C}$ (the highest temperature conditions reported in a UHP orogenic setting), providing evidence for an origin in a mantle plume. Therefore, the Dominican ultramafic rocks may represent the only example of exhumed "fossil fragments" of mantle plume in an orogenic setting (oceanic or continental).
\end{abstract}

(c) 2011 Elsevier B.V. All rights reserved.

\section{Introduction}

Globally scarce ultra high pressure (UHP) rocks associated with folded mountain belts (i.e., orogenic, or "Alpine-type") (e.g., Carswell and Compagnoni, 2003; Carswell and Zhang, 1999; Guillot et al., 2009; Hacker, 2006; Liou et al., 2006) offer a unique "window" into the deep subduction zone processes at convergent plate boundaries. In some orogenic UHP terranes, garnet-bearing ultramafic rocks of mantle origin occur as xenoliths in eclogite (deeply subducted, metamorphosed oceanic crust) (e.g., Medaris, 1999). These ultramafic rocks offer valuable insight into the nature of the mantle adjacent to the subduction zone, the transfer of the mantle rocks to deep-subducted crust (eclogite), chemical modification in the subduction zone, and the still poorly understood mechanism of exhumation.

\footnotetext{
* Corresponding author. Tel.: +1 845365 8507; fax: +1 8453658155 E-mail address: egazel@Ideo.columbia.edu (E. Gazel).
}

Among such UHP rocks, garnet-bearing ultramafic rocks in the Dominican Republic (DR) are unique for a number of reasons (Abbott and Draper, 2008, 2010; Abbott et al., 2005, 2006, 2007): (1) The rocks were exhumed at an ocean-ocean convergent plate boundary, confounding conventional explanations that involve buoyancy. (2) The rocks contain the first-reported occurrence of coexisting garnet + spinel + corundum (Abbott et al., 2005), indicative of very high pressure. The association garnet + spinel + corundum involves the three minerals in mutual contact (spinel + corundum microinclusions in garnet), with neither sapphirine nor plagioclase present. Earlier reports of garnet-spinel-corundum-bearing ultramafic rocks (Kornprobst et al., 1990; Morishito et al., 2001; Zhang et al., 2004) failed this criterion. In these earlier reports, the corundum and spinel are associated with sapphirine, plagioclase, or both. A more recent report of the association (Zong et al., in press) also fails the criterion and the rocks are quartz-bearing, hence not ultramafic in any conventional sense. Coexisting garnet + spinel + corundum by itself precludes sapphirine (Ackermand et al., 1975). (3) The DR rocks 
are the product of fractional crystallization under UHP conditions, $\mathrm{P}>3.2 \mathrm{GPa}$ and solidus $\mathrm{T}>1500^{\circ} \mathrm{C}$. Here, we use major-element mineral chemistry coupled with in-situ trace element data to test the different hypotheses about the origin and tectonic significance of these rocks, focusing mostly on the pegmatitic garnet-clinopyroxenite.

Abbreviations for minerals and components of minerals conform to Kretz (1983; and see Whitney and Evans, 2010). Abbreviations beginning with small-case letters are components (e.g., di, spl, prp, alm, etc.). Capitalized abbreviations refer to mineral-phases (e.g., Grt, Spl, Cpx, Crn, etc.). We depart from Kretz (1983) in defining two generalized pyroxene components, $\mathrm{px}=(\mathrm{Ca}, \mathrm{Mg}, \mathrm{Fe})_{2} \mathrm{Si}_{2} \mathrm{O}_{6}$ and pts $=$ ( $\mathrm{Ca}, \mathrm{Fe}, \mathrm{Mg}) \mathrm{Al}_{2} \mathrm{SiO}_{6}$ (tschermak component), and one generalized component for garnet, grt $=(\mathrm{Ca}, \mathrm{Mg}, \mathrm{Fe})_{3} \mathrm{Al}_{2} \mathrm{Si}_{3} \mathrm{O}_{12}$.

\section{Geological setting}

The Dominican Republic occupies the eastern two-thirds of the island of Hispaniola, near the northern edge of the Caribbean Plate (Fig. 1). The basement of Hispaniola started to form in the Early Cretaceous as part of an intra-oceanic island arc. While debated tectonic reconstructions suggest that the early arc formed above a NEdipping plate of Pacific origin (Draper et al., 1996; Pindell and Barrett, 1990). In the mid-Cretaceous (120-100 Ma) subduction ceased on the Pacific side of the island arc complex only to resume with reversed polarity on the Atlantic side of the complex (Draper et al., 1996; Pindell and Barrett, 1990). Hastie and Kerr (2010) argued that this polarity reversal took place as late as $80 \mathrm{Ma}$. Throughout the Late Cretaceous until the Middle Eocene, Atlantic lithosphere dipped W to SW beneath the $\mathrm{E}$ and NE edge of the Caribbean Plate, and the intraoceanic island arc expanded through magmatism and various other accretionary processes (Draper et al., 1996; Pindell and Barrett, 1990; Pindell et al., 2005). Beginning in the Middle Eocene and continuing to the present, the island arc system has been modified by E-W, leftlateral, transcurrent and transpressional tectonics (Draper et al., 1996; Jansma et al., 2000; Mann et al., 1990, 2002).
The Cordillera Septentrional forms the landscape north of the Septentrional Fault in the Dominican Republic (Fig. 1). The WNW-ESE trending range is made up of Late Eocene to Early Miocene siliciclastic and carbonate sedimentary rocks, underlain by a basement complex of arc-related metamorphic and igneous rocks (Eberle et al., 1982; Lewis and Draper, 1990). The basement is exposed in a number of erosional windows, or "inliers." The largest of these inliers exposes the Rio San Juan Complex (Draper and Nagle, 1991; Eberle et al., 1982).

The Rio San Juan Complex (Draper and Nagle, 1991) is divided into distinct northern and southern parts, which were juxtaposed by faulting, probably in the Paleogene (Draper and Nagle, 1991; Draper et al., 1994). The northern part of the inlier consists of serpentinite and blueschist-eclogite melange with serpentine matrix, faulted against fine-grained, coherent greenschist-blueschist facies rocks. The HP/low temperature (LT) metamorphism of the blueschist and blueschist eclogite is interpreted as having resulted from SW-directed subduction in the Early to Late Cretaceous (Draper and Nagle, 1991; Draper et al., 1994). The southern part of the Rio San Juan Complex (Fig. 1) consists of the Cuaba Gneiss and the Rio Boba Intrusive Complex. The Cuaba Gneiss is predominantly hornblende gneiss and hornblende schist. The common mineral assemblage is hornblende + plagioclase (andesine) + quart + rutile $+/$ - garnet $+/$ - biotite $+/$ - epidote. Draper and Nagle (1991) suggested a mafic protolith (basalt/diabase/gabbro) of ocean-crustal origin. Retrograded eclogite in the Cuaba Gneiss was first reported by Abbott and Draper (1998). The retrograded eclogite occurs as $\mathrm{mm}$ to $\mathrm{dm}$ scale layers in hornblende gneiss. The layers consist of garnet porphyroblasts in plagioclase-clinopyroxene symplectite (Abbott and Draper, 2007). The trace element geochemistry of the eclogite is consistent with MORB. Garnet-ultramafic rocks, which are the subject of this contribution, were first reported by Abbott et al. (2001). The ultramafic rocks occur as stream boulders (up to $5 \mathrm{~m}$ ) that were eroded out of the eclogite in the Cuaba Gneiss (Fig. 1). The ultramafic rocks are interpreted as minor constituents of the gneiss. Field correlations favor a Cretaceous age. The Cuaba Gneiss was subsequently intruded

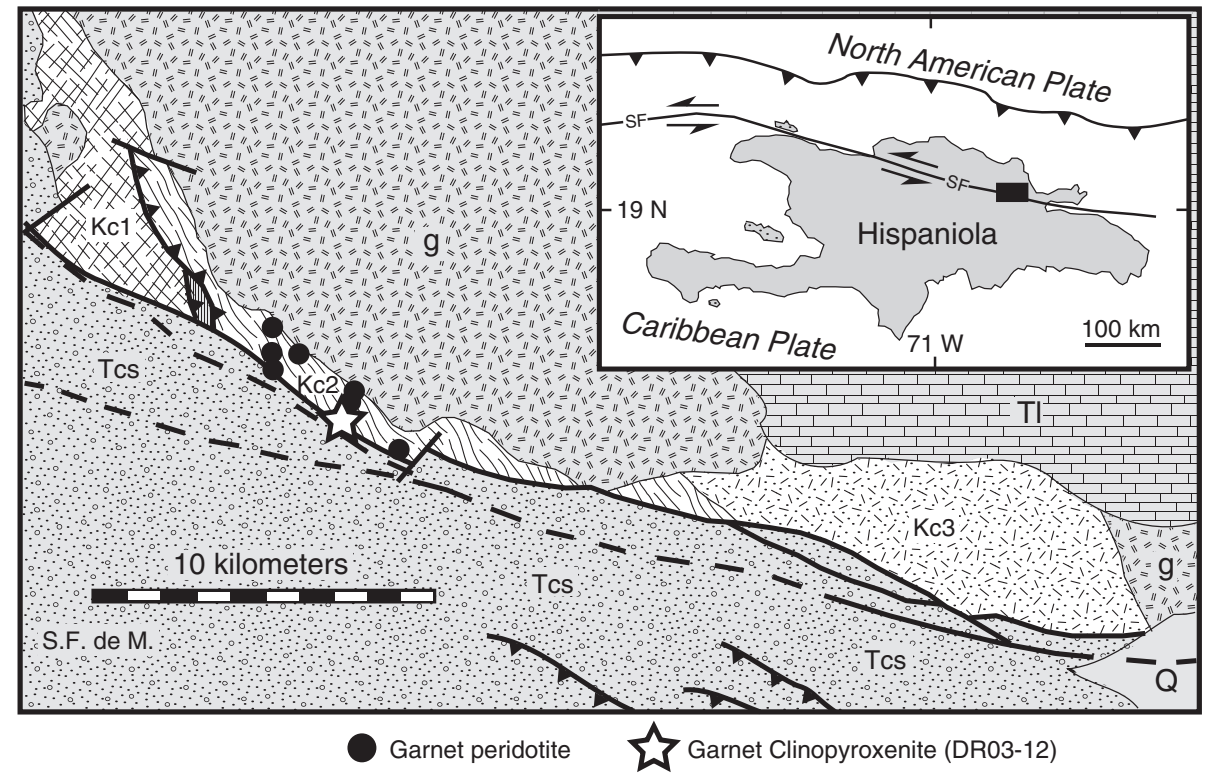

Fig. 1. Geology of the southern part of the Rio San Juan Complex. The Island of Hispaniola is shown in the inset. The Cordillera Septentrional occupies the land north of the Septentrional Fault (SF) in the Dominican Republic. The Septentrional fault (SF) forms the southern margin of the Rio San Juan complex. Movement between the North American Plate and Caribbean Plate is distributed over the Septentrional Fault (SF) and an offshore strongly oblique convergent zone (Jansma et al., 2000; Mann et al., 2002). The study area is marked by the filled rectangle. The Cuaba Gneiss consists of hornblende schist (Kc1), garnet hornblende gneiss (Kc2), and garnet metadiorite (Kc3). The small, vertically ruled (shaded) region between Kc1 and Kc2 is serpentinite, unrelated to the Cuaba Gneiss. Filled circles mark sites where UHP ultramafic rocks were observed or sampled from stream boulders. The Cuaba Gneiss is intruded by the Rio Bobo gabbro complex (g). Younger sedimentary rocks and sediment are Upper Eocene-Miocene clastic sedimentary rocks (Tcs), Neogene limestones ( $\mathrm{Tl}$ ), and Quaternary alluvium (Q). Reverse faults: bold, toothed lines (teeth, on hang wall). Left-lateral strike-slip faults: bold un-ornamented lines, dashed where uncertain. S.F. de M. is the city of San Francisco de Macoris. 
by gabbroic to quartz dioritic rocks of the Rio Boba Intrusive Suite (Draper and Nagle, 1991). The petrogenetic relationship (if any) between the HP/LT rocks in the northern part of the inlier and HP/UHP rocks of the Cuaba Gneiss remains unclear.

\section{Ultra high pressure (UHP) vs. low-pressure (LP)origin}

The UHP hypothesis (Abbott and Draper, 2008; Abbott et al., 2005, 2006, 2007) and the LP hypothesis (Hattori et al., 2010a,b) are illustrated in Fig. 2.

\subsection{UHP hypothesis}

Orthocumulate texture, dikes, pegmatitic mineral segregations, and the sequence of mineral assemblages all point to a magmatic origin for the garnet-bearing ultramafic rocks, $\left(>3.2 \mathrm{GPa},>1500{ }^{\circ} \mathrm{C}\right.$, Fig. 2A and Appendix A) (Abbott and Draper, 2008; Abbott et al., 2005, 2006, 2007). The magma field is defined by the reaction sapphirine $=$ garnet + spinel + corundum (see Appendix A for details) and the peridotite solidus (Herzberg et al., 2000; Hirschmann, 2000). Collectively, the petrology of the ultramafic boulders reveals a

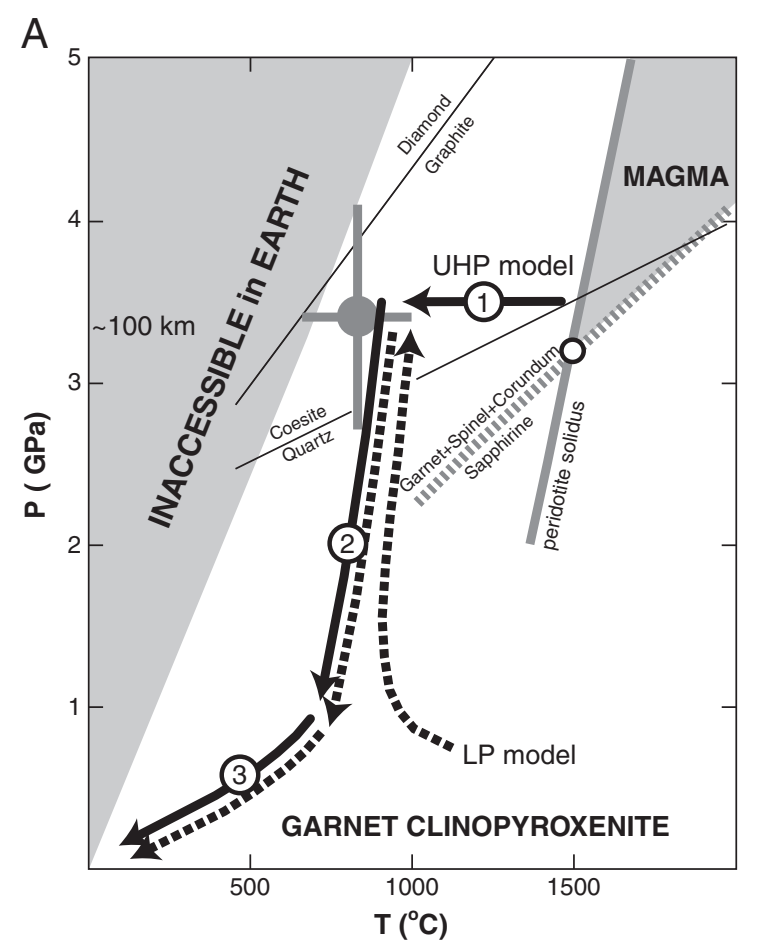

B

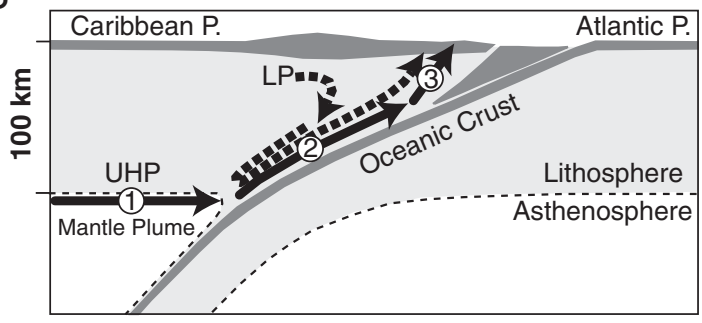

Fig. 2. Diagrams illustrating different interpretations of the P-T path for the origin of garnet-bearing ultramafic rocks in the Cuaba Gneiss, northern Dominican Republic. A. The UHP model (Abbott et al., 2005, 2006, 2007; Abbott and Draper, 2008 and Appendix A) and the LP model (Hattori et al., 2010a,b) are illustrated. B. Schematic representation of the Late Cretaceous convergent plate boundary involving the North American plate and the Caribbean plate, with paths for the UHP model and the LP model (Hattori et al., 2010a). liquid-line-of-descent (LLD) from a primary olivine-saturated melt (e.g., Herzberg and Gazel, 2009) to corundum-bearing garnetclinopyroxenite. The LLD involved the following products of fractional crystallization, from high to low temperature (Abbott et al., 2007):

(I) Olivine-clinopyroxenite (clinopyroxene + olivine + orthopyroxene),

(II) Garnet-olivine-clinopyroxenite (clinopyroxene + olivine + garnet),

(III) Garnet-peridotite (DR03-10, clinopyroxene + olivine + garnet + spinel),

(IV) Garnet-clinopyroxenite (clinopyroxene + garnet + spinel),

(V) Pegmatitic garnet-clinopyroxenite (DR03-12, clinopyroxene + garnet + spinel + corundum).

The LLD is consistent with phase relationships in the system $\mathrm{Mg}_{2} \mathrm{SiO}_{4}-\mathrm{SiO}_{2}-\mathrm{CaMgSi}_{2} \mathrm{O}_{6}-\mathrm{CaAl}_{2} \mathrm{Si}_{2} \mathrm{O}_{8}$ at $\mathrm{P}>3.2 \mathrm{GPa}$ (Abbott et al., 2005, 2007; and Appendix A). Unfortunately, details of the original condition of the rocks have been partially obscured by a protracted subsolidus history (Fig. 2) (Abbott and Draper, 2008; Abbott et al., 2006; and Appendix A).

The large, filled circle with error bars (st. dev.) in Fig. 2A represents THERMOCALC (Holland and Powell, 1998; Powell, 2005; Powell et al., 1998) results for the subsolidus equilibrium involving garnet + spinel + clinopyroxene + olivine of the garnet-peridotite (3.4 GPa, $838^{\circ} \mathrm{C}$, assemblage III, DR03-12) (Appendix A). According to the UHP hypothesis (Abbott and Draper, 2008, 2010; Abbott et al., 2005, 2006, 2007), starting from magma $\left(>1500^{\circ} \mathrm{C},>3.2 \mathrm{GPa}\right)$, the subsolidus history involved three stages (Fig. 2) as follows: (1) approximately isobaric cooling down to $\sim 850^{\circ} \mathrm{C}(>3.2 \mathrm{GPa}),(2)$ adiabatic decompression to $\sim 1.5 \mathrm{GPa}$ and $\sim 750^{\circ} \mathrm{C}$, and (3) non-adiabatic decompression and cooling (mediated by $\mathrm{H}_{2} \mathrm{O}$ ) through crustal conditions to the surface.

\subsection{LP hypothesis}

In constrast, prior to stage 2, the LP hypothesis (Abbott and Draper, 2010; Hattori et al., 2010a,b) involved a very different path of increasing pressure, starting from a LP plagioclase-bearing igneous protolith (Fig. 2). The hypothesis is based on a small, positive Eu anomaly (Hattori et al., 2010a) in the bulk-rock chemistry of two samples of garnet-peridotite (assemblage III), and REE modeling involving the REE chemistry of the clinopyroxene. Bulk-rock chemical analyses of four additional samples (Hattori et al., 2010b) show that two of the four additional samples have negative $\mathrm{Eu}$ anomalies, another sample has no Eu anomaly, and only one of the four additional samples has a positive Eu anomaly. The least altered sample (lowest LOI $=1.5$ wt.\%, Hattori et al., 2010b) shows a negative Eu anomaly. The chemistry of the clinopyroxene used in the modeling is compromised by late arc-related metasomatism, as evidenced by the partial replacement of the clinopyroxene by hornblende (Abbott and Draper, 2010). The major-element chemistry of the clinopyroxene is also inconsistent with a primary igneous composition. Likewise, the hypothetical REE chemistry for garnet used in the modeling is inconsistent with the actual REE chemistry of the garnet presented in this study (below). The P-T paths for both hypotheses (UHP vs. LP) are the same for stages 2 and 3, and compatible with the retrograde P-T history of the eclogite host (Abbott and Draper, 2007).

\section{Analytical methods}

\subsection{Major-element mineral chemistry}

Chemical analyses of major-element oxides (Table 1) were performed at the College of Arts and Sciences Microscope Facility, Appalachian State University, by scanning electron microscopeenergy dispersive spectroscopy (SEM-EDS). The instrument was an 
Table 1

Major-element mineral chemistry for the garnet-clinopyroxenite. ${ }^{\text {a }}$

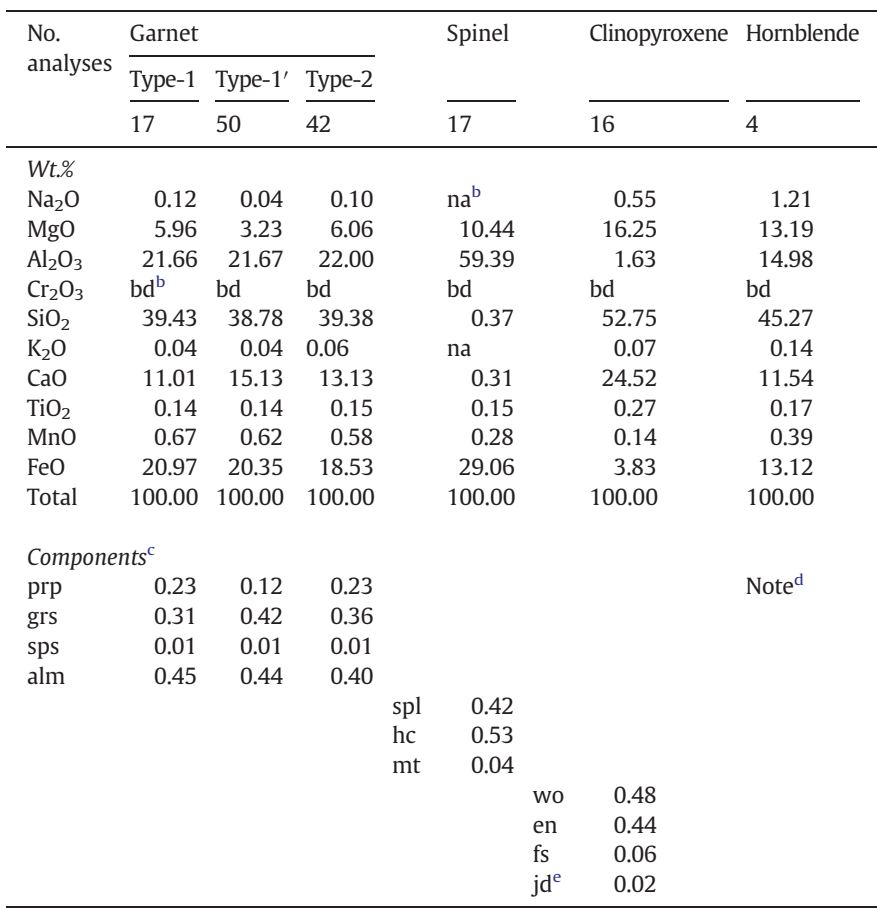

a Notes: Sample DR03-12. Uncertainty: Tests on standards indicate reproducible results to within $\sim 1 \%$ of the wt.\% reported for major oxide-components ( $\mathrm{MgO}, \mathrm{Al}_{2} \mathrm{O}_{3}$, $\mathrm{SiO}_{2}, \mathrm{CaO}$, and $\mathrm{FeO}$ ), and to within $\sim 10 \%$ of the wt.\% reported for minor oxidecomponents $\left(\mathrm{Na}_{2} \mathrm{O}, \mathrm{K}_{2} \mathrm{O}, \mathrm{TiO}_{2}\right.$, and $\left.\mathrm{MnO}\right)$.

${ }^{\mathrm{b}}$ na $=$ not analyzed. bd = below detection (No counts above background in EDS).

c Abbreviations for components conform to guidelines of Kretz (1983).

d Hornblende: $\mathrm{Na}_{0.28} \mathrm{~K}_{0.02} \mathrm{Ca}_{1.74} \mathrm{Mg}_{2.97} \mathrm{Fe}_{1.46} \mathrm{Mn}_{0.05} \mathrm{Ti}_{0.02} \mathrm{Al}_{2.18} \mathrm{Si}_{6.58} \mathrm{O}_{22}(\mathrm{OH})_{2}$ normalized to $\mathrm{Mg}+\mathrm{Al}+\mathrm{Si}+\mathrm{Ca}+\mathrm{Ti}+\mathrm{Mn}+\mathrm{Fe}=15$, i.e., relegating $\mathrm{Na}+\mathrm{K}$ to the $\mathrm{A}$-site.

e $\mathrm{jd}=\mathrm{Na}_{0.5} \mathrm{Al}_{0.5} \mathrm{SiO}_{3}$, in order that all pyroxene components are normalized to 3 "O."

FEI Quanta 200 SEM, fitted with an EDAX EDS. Operating conditions were: high-vacuum, $35 \mathrm{kV}, 2-4 \mu \mathrm{m}$ spot-size, 50 s counts. U.S. National Museum standards were used: USNM garnet 110752, USNM omphacite 110607. Data reduction involved proprietary (EDAX) ZAF correction that constrains the total wt.\% oxides to $100 \mathrm{wt} . \%$. Uncertainty is reported in the footnote to Table $1 . \mathrm{Cr}_{2} \mathrm{O}_{3}$ is below detection in ED spectra for all of the analyzed minerals. This is consistent with Hattori et al. (2010a), who reported only traces of this component in garnet (0.02 wt.\% $\mathrm{Cr}_{2} \mathrm{O}_{3}$ ), spinel (0.03-0.12 wt.\% $\left.\mathrm{Cr}_{2} \mathrm{O}_{3}\right)$ and clinopyroxene (0.1-0.21 wt.\% $\left.\mathrm{Cr}_{2} \mathrm{O}_{3}\right)$ from their garnet-wehrlite, which is equivalent to our garnet-peridotite (assemblage III). We prefer the term peridotite because IUGS terminology provides little guidance for ultramafic rock with 20 vol.\% or more garnet and comparable amounts of hydrated minerals. Peridotite is an acceptable general term (IUGS) that includes wehrlite, lherzolite and harzburgite.

\subsection{Trace-element mineral chemistry}

Garnet and clinopyroxene trace-element concentrations (Tables 2 and 3) were determined at Lamont-Doherty Earth Observatory of Columbia University by laser-ablation inductively coupled plasma mass spectrometry (LA-ICP-MS) in areas carefully selected away from inclusions and fractures. The analyses were performed with a UP-193 Excimer laser ablation system from New Wave coupled to a VG PQ ExCell quadrupole ICP-MS. Samples were ablated in He at a flow rate of $1.5 \mathrm{~L} / \mathrm{min}$. The laser was operated in spot-drill mode at $10 \mathrm{~Hz}$, at $60 \%$ (irradiance of $\sim 1.30-1.90 \mathrm{Gw} / \mathrm{cm}^{2}$ and fluency of $\sim 7-10 \mathrm{~J} / \mathrm{cm}^{2}$ ). The laser spot size was $\sim 100 \mu \mathrm{m}$. Data was collected for $120 \mathrm{~s}$, including $60 \mathrm{~s}$ of background when the laser was off. Dwell time for most elements was $10 \mathrm{~ms}$, except the rare earth elements, $\mathrm{Hf}, \mathrm{Pb}, \mathrm{Th}$, and $U$ (dwell time of $50 \mathrm{~ms}$ ). Laser data were acquired in timeresolved mode, and calibrated against United States Geological Survey standard glasses BHVO-2g, BIR-1g, and BCR-2g, using ${ }^{43} \mathrm{Ca}$ as an internal standard. The average precision for four replicate analyses of BIR-1g was $<10 \%$ RSD for all elements. Cr-Augite pyroxene, San Carlos olivine and K-23 in-house garnet standard were analyzed together with the unknowns for comparison and the data are available upon request. For more details about the LA-ICP-MS methods please see Cooper et al. (2010).

\section{Results}

\subsection{Pegmatitic garnet-clinopyroxenite unique mineral composition}

This study focuses on the mineralogy of pegmatitic garnetclinopyroxenite (assemblage V, sample DR03-12). The rock consists of clinopyroxene megacrysts (up to $3 \mathrm{~cm}$ ) in a garnet matrix (Fig. 3 ). Late hornblende forms narrow rims (typically $<1 \mathrm{~mm}$ ) on the clinopyroxene, and also occurs in profusion as $\mu \mathrm{m}$-scale inclusions in the clinopyroxene. Microinclusions $(<0.1 \mathrm{~mm})$ of spinel (var. hercynite) and corundum occur in garnet, but not in the clinopyroxene. The garnet occurs in three texturally (Fig. 3B) and compositionally (Fig. 4A and Table 1) distinct forms: Type-1 garnet (low Ca, high $\mathrm{Mg}$ ) has microinclusions of both spinel and corundum and is not associated with clinopyroxene or hornblende. Type- $1^{\prime}$ garnet (high $\mathrm{Ca}$, low $\mathrm{Mg}$ ) forms the bulk of the garnet, with few inclusions of spinel and very rare inclusions of corundum. Type- $1^{\prime}$ garnet is generally not associated with clinopyroxene or hornblende. Locally type- $1^{\prime}$ garnet displays crystal faces (Fig. 3B). Type-2 garnet (intermediate Ca, high $\mathrm{Mg}$, low $\mathrm{Fe}+\mathrm{Mn}$ ) is associated with hornblende near clinopyroxene and is most conspicuously associated with hornblende as overgrowths on crystal faces of type- 1 ' garnet. Type- 2 garnet has neither inclusions of spinel nor inclusions of corundum. Opaque minerals include pyrite and pentlandite.

\subsection{Major-element mineral chemistry}

Chemical analyses of type- 1 garnet and type- $1^{\prime}$ garnet compare favorably with phase relationships at P>3.2 GPa (Fig. 4B) (Abbott and Draper, 2008; Abbott et al., 2005). In the phase relationships, the projected locus of liquids (silicate melt) coexisting with garnet + clinopyroxene + spinel (assemblage IV) is shown as a bold, straight, black bar in Fig. 4B (Abbott et al., 2005). The locus represents a very small cooling interval, $<30{ }^{\circ} \mathrm{C}$ (Abbott et al., 2005). At the high-temperature end of the locus (farthest from $\mathrm{Al}_{2} \mathrm{O}_{3}$ ), the liquid is saturated with respect to olivine (assemblage III). At the low-temperature end of the locus (closest to $\mathrm{Al}_{2} \mathrm{O}_{3}$ ), the liquid is saturated with respect to corundum (assemblage V). Experimentally determined compositions of the minerals (Milholland and Presnall, 1998) coexisting with a similar "low-temperature" liquid are close to the apices of the open triangles in Fig. 4B (Abbott et al., 2005). According to the UHP hypothesis, the corundum-bearing pegmatitic garnet-linopyroxenite (Fig. 3A,B) (assemblage V) crystallized from such a liquid.

Type-1 garnet approaches the solidus composition for garnet at $\mathrm{P}>3 \mathrm{GPa}$ (Fig. 4B), and type- 1 ' garnet is close to the solidus composition for clinopyroxene (high-Al, Fig. 4B). Abbott and Draper (2008, 2010) postulated that the type- 1 ' garnet formed approximately isochemically from UHP magmatic clinopyroxene as a result of subsolidus processes. Two multivariant reactions are relevant, expressed in terms of components in clinopyroxene and garnet:

$1 \mathrm{px}^{\mathrm{Cpx}}+1 \mathrm{pts}^{\mathrm{Cpx}}=1 \mathrm{grt}^{\mathrm{Grt}}$

and

$3 \mathrm{pts}^{\mathrm{Cpx}}=1 \mathrm{grt}^{\mathrm{Grt}}+2 \mathrm{Crn}$, 
Table 2

Trace-element analyses, garnet-clinopyroxenite (DR03-12) ${ }^{1}$.

\begin{tabular}{|c|c|c|c|c|c|c|c|c|c|c|c|c|}
\hline \multirow[b]{2}{*}{ Sample } & \multicolumn{4}{|c|}{ Type-1 Garnet } & & \multicolumn{7}{|c|}{ Type-1' Garnet } \\
\hline & 15 & $32 \mathrm{~A}$ & $32 \mathrm{~B}$ & $47-56$ & & 1 & & 28 & 29 & 33 & 46 & $46 \mathrm{~B}$ \\
\hline $\mathrm{Li}$ & 0.596 & 0.950 & 0.839 & 3.30 & & 0.041 & & 0.036 & 0.094 & bd & 0.050 & 0.064 \\
\hline Sc & 1.87 & 3.26 & 6.49 & 2.97 & & 1.26 & & 1.42 & 3.02 & 1.55 & 1.38 & 2.53 \\
\hline $\mathrm{TiO}_{2}$, wt. \% & 0.011 & 0.009 & 0.028 & 0.011 & & 0.009 & & 0.009 & 0.017 & 0.010 & 0.008 & 0.010 \\
\hline V & 18.87 & 18.95 & 41.90 & 21.31 & & 21.06 & & 20.69 & 51.90 & 21.72 & 18.80 & 21.08 \\
\hline $\mathrm{Cr}$ & 5.50 & 3.25 & 30.22 & 6.30 & & 4.23 & & 4.38 & 4.08 & 5.17 & 4.41 & 3.50 \\
\hline Co & 47.73 & 46.93 & 48.04 & 38.51 & & 49.54 & & 48.56 & 57.01 & 50.45 & 42.18 & 51.48 \\
\hline $\mathrm{Ni}$ & 0.533 & 1.18 & 2.04 & 4.04 & & bd & & bd & 0.755 & 0.298 & 0.324 & 0.634 \\
\hline $\mathrm{Cu}$ & 0.585 & 0.123 & 0.209 & 0.117 & & 0.037 & & 0.059 & 0.157 & 0.157 & 0.093 & 0.165 \\
\hline $\mathrm{Zn}$ & 10.43 & 9.07 & 13.04 & 8.99 & & 9.67 & & 8.92 & 9.46 & 9.46 & 8.92 & 9.47 \\
\hline $\mathrm{Rb}$ & 0.015 & 0.005 & 0.006 & 0.142 & & bd & & bd & 0.003 & bd & 0.002 & 0.003 \\
\hline $\mathrm{Sr}$ & 0.353 & 12.48 & 5.44 & 0.206 & & 0.086 & & 2.41 & 0.642 & 5.68 & 43.60 & 5.41 \\
\hline $\mathrm{Y}$ & 1.13 & 1.76 & 1.39 & 1.52 & & 0.444 & & 0.561 & 1.16 & 0.612 & 0.701 & 0.665 \\
\hline $\mathrm{Zr}$ & 0.292 & 0.171 & 0.291 & 0.337 & & 0.087 & & 0.127 & 0.276 & 0.125 & 0.126 & 0.146 \\
\hline $\mathrm{Nb}$ & 0.002 & bd & 0.002 & bd & & bd & & bd & bd & bd & bd & bd \\
\hline $\mathrm{Ba}$ & 0.068 & 0.102 & 0.037 & 0.278 & & 0.021 & & 0.028 & 0.005 & 0.042 & 0.445 & 0.041 \\
\hline $\mathrm{La}$ & 0.007 & 0.113 & 0.012 & 0.029 & & 0.031 & & 0.075 & 1.34 & 0.142 & 0.554 & 0.144 \\
\hline $\mathrm{Ce}$ & 0.014 & 0.211 & 0.017 & 0.033 & & 0.047 & & 0.107 & 2.69 & 0.207 & 0.973 & 0.263 \\
\hline $\mathrm{Pr}$ & bd & 0.038 & 0.003 & 0.007 & & 0.011 & & 0.016 & 0.476 & 0.031 & 0.162 & 0.044 \\
\hline $\mathrm{Nd}$ & 0.043 & 0.286 & 0.065 & 0.109 & & 0.090 & & 0.099 & 2.86 & 0.169 & 0.825 & 0.262 \\
\hline $\mathrm{Sm}$ & 0.273 & 0.664 & 0.138 & 0.234 & & 0.483 & & 0.445 & 3.52 & 0.447 & 0.546 & 0.460 \\
\hline $\mathrm{Eu}$ & 0.704 & 1.33 & 0.160 & 0.269 & & 1.22 & & 1.12 & 6.51 & 1.09 & 1.16 & 1.08 \\
\hline Gd & 1.18 & 2.17 & 0.419 & 0.844 & & 1.66 & & 1.62 & 10.89 & 1.48 & 1.40 & 1.61 \\
\hline $\mathrm{Tb}$ & 0.126 & 0.204 & 0.084 & 0.141 & & 0.133 & & 0.142 & 0.687 & 0.130 & 0.123 & 0.140 \\
\hline Dy & 0.486 & 0.682 & 0.525 & 0.636 & & 0.333 & & 0.351 & 1.09 & 0.364 & 0.376 & 0.403 \\
\hline Ho & 0.058 & 0.093 & 0.078 & 0.086 & & 0.026 & & 0.031 & 0.070 & 0.035 & 0.040 & 0.037 \\
\hline $\mathrm{Er}$ & 0.131 & 0.188 & 0.128 & 0.153 & & 0.037 & & 0.053 & 0.098 & 0.05 & 0.065 & 0.058 \\
\hline $\mathrm{Tm}$ & 0.014 & 0.020 & 0.014 & 0.016 & & 0.005 & & 0.005 & 0.011 & 0.004 & 0.005 & 0.006 \\
\hline $\mathrm{Yb}$ & 0.089 & 0.123 & 0.065 & 0.093 & & 0.033 & & 0.035 & 0.074 & 0.035 & 0.031 & 0.035 \\
\hline Lu & 0.011 & 0.016 & 0.009 & 0.014 & & 0.004 & & 0.004 & 0.012 & 0.006 & 0.005 & 0.006 \\
\hline $\mathrm{Hf}$ & 0.009 & 0.009 & 0.011 & 0.012 & & 0.006 & & 0.005 & 0.031 & 0.007 & 0.008 & 0.011 \\
\hline $\mathrm{Ta}$ & bd & bd & bd & bd & & bd & & bd & bd & bd & bd & bd \\
\hline $\mathrm{Pb}$ & 0.048 & 0.040 & 0.036 & 0.018 & & 0.013 & & 0.016 & 0.032 & 0.025 & 0.195 & 0.044 \\
\hline Th & bd & bd & bd & bd & & bd & & bd & 0.033 & 0.007 & 0.001 & 0.004 \\
\hline \multirow[t]{2}{*}{$\mathrm{U}$} & 0.006 & 0.012 & 0.005 & 0.005 & & 0.005 & & 0.003 & 0.050 & 0.004 & 0.031 & 0.008 \\
\hline & \multicolumn{7}{|c|}{ Type-2 Garnet } & & \multicolumn{4}{|c|}{ Clinopyroxene } \\
\hline Sample & A10 & A70 & 24 & & $24 \mathrm{~B}$ & & 38 & & P1b & P1c & $\mathrm{P} 2 \mathrm{~b}$ & $\mathrm{P} 2 \mathrm{c}$ \\
\hline $\mathrm{Li}$ & 2.80 & 0.372 & 0.729 & & 0.090 & & bd & & 4.22 & 4.39 & 13.33 & 9.22 \\
\hline Sc & 7.49 & 5.21 & 5.25 & & 10.31 & & 5.44 & & 144.1 & 105.2 & 232.1 & 257.7 \\
\hline $\mathrm{TiO}_{2}$, wt. \% & 0.010 & 0.007 & 0.008 & & 0.006 & & 0.007 & & 0.201 & 0.096 & 0.512 & 0.784 \\
\hline V & 23.76 & 22.89 & 20.78 & & 18.83 & & 18.44 & & 336.3 & 278.9 & 1170 & 1287 \\
\hline $\mathrm{Cr}$ & 6.16 & 7.22 & 5.52 & & 5.30 & & 5.10 & & 1016 & 888.3 & 3448 & 3525 \\
\hline Co & 44.83 & 28.16 & 30.74 & & 31.43 & & 31.07 & & 38.36 & 36.12 & 118.2 & 116.9 \\
\hline $\mathrm{Ni}$ & 6.34 & 0.584 & 1.25 & & 0.636 & & 0.552 & & 72.97 & 77.59 & 373.2 & 396.8 \\
\hline $\mathrm{Cu}$ & 0.183 & 0.138 & 0.159 & & 0.202 & & 0.160 & & 4.57 & 6.92 & 51.56 & 45.26 \\
\hline Zn & 4.46 & 2.66 & 2.87 & & 2.83 & & 2.92 & & 18.35 & 19.22 & 49.87 & 71.92 \\
\hline $\mathrm{Rb}$ & 0.034 & 0.092 & 0.046 & & 0.008 & & 0.002 & & 2.22 & 1.78 & 13.71 & 16.46 \\
\hline $\mathrm{Sr}$ & 0.092 & 0.054 & 0.101 & & 0.051 & & 0.153 & & 65.33 & 43.70 & 195.0 & 214.7 \\
\hline$Y$ & 6.64 & 6.20 & 6.19 & & 8.70 & & 5.77 & & 3.43 & 1.21 & 7.81 & 8.33 \\
\hline $\mathrm{Zr}$ & 0.684 & 0.780 & 0.763 & & 0.944 & & 0.606 & & 0.873 & 0.521 & 4.35 & 4.20 \\
\hline $\mathrm{Nb}$ & bd & bd & 0.002 & & bd & & bd & & 0.011 & 0.006 & 0.092 & 0.095 \\
\hline $\mathrm{Ba}$ & 0.046 & 0.059 & 0.059 & & 0.004 & & 0.011 & & 53.41 & 33.10 & 195.6 & 224.6 \\
\hline La & 0.035 & 0.025 & 0.041 & & 0.008 & & 0.001 & & 0.038 & 0.031 & 0.275 & 0.369 \\
\hline $\mathrm{Ce}$ & 0.048 & 0.043 & 0.068 & & 0.019 & & 0.011 & & 0.169 & 0.116 & 0.881 & 0.926 \\
\hline $\mathrm{Pr}$ & 0.016 & 0.016 & 0.019 & & 0.012 & & 0.008 & & 0.051 & 0.026 & 0.257 & 0.233 \\
\hline $\mathrm{Nd}$ & 0.309 & 0.346 & 0.360 & & 0.372 & & 0.253 & & 0.413 & 0.177 & 1.95 & 1.51 \\
\hline $\mathrm{Sm}$ & 1.20 & 1.33 & 1.27 & & 1.50 & & 1.04 & & 0.267 & 0.100 & 1.34 & 0.933 \\
\hline $\mathrm{Eu}$ & 0.547 & 0.570 & 0.396 & & 0.454 & & 0.344 & & 0.121 & 0.061 & 0.513 & 0.431 \\
\hline Gd & 3.03 & 3.07 & 3.12 & & 3.46 & & 2.51 & & 0.512 & 0.173 & 1.67 & 1.67 \\
\hline $\mathrm{Tb}$ & 0.420 & 0.413 & 0.357 & & 0.438 & & 0.307 & & 0.098 & 0.032 & 0.269 & 0.280 \\
\hline Dy & 2.23 & 2.11 & 1.98 & & 2.51 & & 1.68 & & 0.697 & 0.231 & 1.70 & 1.80 \\
\hline Ho & 0.347 & 0.332 & 0.322 & & 0.445 & & 0.296 & & 0.151 & 0.051 & 0.342 & 0.355 \\
\hline $\mathrm{Er}$ & 0.675 & 0.615 & 0.636 & & 0.961 & & 0.611 & & 0.405 & 0.143 & 0.884 & 0.895 \\
\hline $\mathrm{Tm}$ & 0.071 & 0.056 & 0.060 & & 0.103 & & 0.065 & & 0.053 & 0.021 & 0.111 & 0.116 \\
\hline $\mathrm{Yb}$ & 0.353 & 0.313 & 0.329 & & 0.585 & & 0.391 & & 0.358 & 0.133 & 0.752 & 0.815 \\
\hline Lu & 0.044 & 0.040 & 0.037 & & 0.085 & & 0.052 & & 0.055 & 0.021 & 0.114 & 0.104 \\
\hline $\mathrm{Hf}$ & 0.018 & 0.018 & 0.016 & & 0.018 & & 0.015 & & 0.091 & 0.065 & 0.343 & 0.400 \\
\hline Ta & 0.001 & bd & bd & & 0.002 & & bd & & bd & bd & 0.003 & 0.004 \\
\hline $\mathrm{Pb}$ & 0.023 & 0.016 & 0.016 & & 0.023 & & 0.015 & & 6.42 & 2.47 & 2.62 & 2.11 \\
\hline Th & bd & bd & bd & & bd & & bd & & 0.004 & 0.006 & 0.007 & 0.009 \\
\hline $\mathrm{U}$ & 0.007 & 0.015 & 0.008 & & 0.006 & & 0.006 & & 0.010 & 0.008 & 0.025 & 0.036 \\
\hline
\end{tabular}

${ }^{1}$ Analyses in ppm, unless otherwise indicated, bd= below detection. Data with enough significant figures to represent the 1-10\% precision. 
Table 3

Trace-element analyses, garnet-peridodite (DR03-10) ${ }^{1}$.

\begin{tabular}{|c|c|c|c|c|c|c|c|c|c|}
\hline \multirow[b]{2}{*}{ Sample } & \multicolumn{3}{|c|}{ Garnet } & \multicolumn{3}{|c|}{ Clinopyroxene } & \multicolumn{3}{|c|}{ Olivine } \\
\hline & Grt-1 & Grt-2 & Grt-3 & Cpx-1 & Cpx-2 & Cpx-3 & Ol-1 & $\mathrm{Ol}-2$ & Ol-3 \\
\hline $\mathrm{Li}$ & 0.218 & 0.200 & 0.524 & 1.27 & 1.57 & 1.40 & 15.18 & 14.93 & 5.54 \\
\hline $\mathrm{Sc}$ & 9.25 & 1.81 & 1.49 & 126.8 & 136.8 & 128.6 & 17.49 & 22.42 & 6.64 \\
\hline $\mathrm{TiO}_{2}$, wt. \% & 0.037 & 0.010 & 0.010 & 0.234 & 0.228 & 0.226 & 0.005 & 0.007 & 0.002 \\
\hline V & 32.79 & 4.38 & 4.02 & 283.2 & 284.3 & 289.3 & 1.23 & 1.19 & 0.347 \\
\hline $\mathrm{Cr}$ & 15.88 & 2.65 & 3.91 & 1028 & 1723 & 1674 & 27.15 & 36.70 & 10.32 \\
\hline Co & 34.71 & 54.22 & 29.30 & 33.21 & 33.75 & 31.34 & 2251 & 2930 & 843.3 \\
\hline $\mathrm{Ni}$ & 8.34 & 47.63 & 7.06 & 66.32 & 69.55 & 65.13 & 5370 & 6843 & 1984 \\
\hline $\mathrm{Cu}$ & 0.257 & 0.370 & 0.333 & 1.62 & 1.31 & 1.16 & 11.47 & 14.03 & 4.60 \\
\hline Zn & 21.06 & 258.8 & 8.22 & 18.79 & 19.28 & 21.33 & 191.2 & 313.0 & 80.8 \\
\hline $\mathrm{Rb}$ & 0.024 & 0.100 & 0.004 & 0.103 & 0.381 & 0.231 & bd & 0.362 & 2.92 \\
\hline $\mathrm{Sr}$ & 1.61 & 1.07 & 0.249 & 15.35 & 16.92 & 12.23 & 1.55 & 1.52 & 0.593 \\
\hline $\mathrm{Y}$ & 1.50 & 0.910 & 0.756 & 4.96 & 4.75 & 4.27 & bd & bd & 0.037 \\
\hline $\mathrm{Zr}$ & 1.02 & 0.160 & 0.132 & 2.22 & 2.28 & 2.40 & 0.147 & 0.146 & 1.81 \\
\hline $\mathrm{Nb}$ & 0.002 & bd & 0.006 & 0.007 & 0.006 & 0.006 & 0.010 & bd & 0.007 \\
\hline $\mathrm{Ba}$ & 0.487 & 1.00 & 0.262 & 1.70 & 6.17 & 0.919 & 1.26 & 1.22 & 4.52 \\
\hline La & 0.012 & 0.010 & 0.015 & 0.149 & 0.164 & 0.175 & 0.010 & bd & 0.038 \\
\hline $\mathrm{Ce}$ & 0.023 & 0.020 & 0.013 & 0.570 & 0.566 & 0.570 & bd & 0.066 & 0.127 \\
\hline $\operatorname{Pr}$ & 0.002 & bd & 0.001 & 0.133 & 0.124 & 0.123 & 0.006 & 0.024 & 0.007 \\
\hline $\mathrm{Nd}$ & 0.017 & 0.020 & 0.009 & 0.928 & 0.843 & 0.797 & bd & bd & 0.066 \\
\hline $\mathrm{Sm}$ & 0.034 & 0.030 & 0.050 & 0.496 & 0.430 & 0.394 & 0.040 & 0.077 & bd \\
\hline $\mathrm{Eu}$ & 0.064 & 0.020 & 0.029 & 0.180 & 0.179 & 0.167 & bd & bd & 0.009 \\
\hline Gd & 0.254 & 0.140 & 0.258 & 0.807 & 0.769 & 0.727 & 0.030 & bd & 0.007 \\
\hline $\mathrm{Tb}$ & 0.050 & 0.030 & 0.043 & 0.144 & 0.140 & 0.126 & 0.010 & bd & bd \\
\hline Dy & 0.340 & 0.200 & 0.244 & 0.997 & 0.953 & 0.850 & bd & 0.011 & 0.005 \\
\hline Ho & 0.066 & 0.040 & 0.034 & 0.207 & 0.195 & 0.177 & 0.003 & 0.002 & 0.004 \\
\hline $\mathrm{Er}$ & 0.158 & 0.100 & 0.072 & 0.560 & 0.540 & 0.483 & 0.034 & bd & bd \\
\hline $\mathrm{Tm}$ & 0.020 & 0.010 & 0.009 & 0.078 & 0.073 & 0.061 & 0.007 & 0.002 & bd \\
\hline $\mathrm{Yb}$ & 0.141 & 0.080 & 0.043 & 0.462 & 0.470 & 0.430 & bd & 0.016 & 0.007 \\
\hline $\mathrm{Lu}$ & 0.023 & 0.010 & 0.005 & 0.073 & 0.071 & 0.065 & bd & bd & bd \\
\hline $\mathrm{Hf}$ & 0.027 & bd & 0.004 & 0.122 & 0.134 & 0.122 & bd & bd & 0.082 \\
\hline Та & bd & bd & bd & 0.001 & 0.001 & bd & 0.003 & bd & bd \\
\hline $\mathrm{Pb}$ & 0.025 & 0.070 & 0.858 & 0.051 & 0.393 & 0.138 & 0.121 & 0.334 & 0.830 \\
\hline Th & 0.002 & 0.010 & 0.011 & 0.009 & 0.014 & 0.015 & bd & bd & 0.007 \\
\hline $\mathrm{U}$ & 0.003 & 0.010 & 0.025 & 0.008 & 0.019 & 0.012 & 0.005 & 0.011 & 0.019 \\
\hline
\end{tabular}

${ }^{1}$ Analyses in ppm, unless otherwise indicated, bd = below detection. Data with enough significant figures to represent the 1-10\% precision.

where $\mathrm{px}=(\mathrm{Ca}, \mathrm{Mg}, \mathrm{Fe})_{2} \mathrm{Si}_{2} \mathrm{O}_{6}$ (generalized pyroxene component) and $\mathrm{pts}=(\mathrm{Ca}, \mathrm{Mg}, \mathrm{Fe}) \mathrm{Al}_{2} \mathrm{SiO}_{6}$ (generalized tschermak component in clinopyroxene), grt $=(\mathrm{Ca}, \mathrm{Mg}, \mathrm{Fe})_{3} \mathrm{Al}_{2} \mathrm{Si}_{3} \mathrm{O}_{12}$ (generalized garnet component), and $\mathrm{Crn}=$ corundum. If the clinopyroxene is more aluminous than garnet, the transformation to type-1' garnet would involve the production of corundum in trace amounts [reaction (2)].

The composition of the clinopyroxene megacrysts (Table 1 ) plots close to diopside-hedenbergite, $\mathrm{Ca}(\mathrm{Mg}, \mathrm{Fe}) \mathrm{Si}_{2} \mathrm{O}_{6}$, within the $900{ }^{\circ} \mathrm{C}$ subsolidus field for clinopyroxene (Fig. 4B). The megacrysts are chemically homogeneous from core to rim (Abbott and Draper, 2008; Abbott et al., 2006,2007). We interpret the clinopyroxene to be secondary, as the product of late retrograde hydration of the cores of primary magmatic phenocrysts. The composition of the hypothetical, primary cores would have been less aluminous than the final magmatic clinopyroxene ( $\sim 50 \mathrm{~mol} \% \mathrm{pts})$ of assemblage $\mathrm{V}$. In the limiting case of a liquid coexisting with clinopyroxene + olivine + garnet + spinel (assemblage III), at the high-temperature end of the projected locus of liquids in Fig. 4B (black bar), the composition of the clinopyroxene would be at the clinopyroxene apex of the projected field for garnet + clinopyroxene + olivine in Fig. 4B, with $\sim 25 \mathrm{~mol} \%$ pts ( $\left.12 \mathrm{~mol} \% \mathrm{Al}_{2} \mathrm{O}_{3}\right)$. We suggest (also see Abbott and Draper, 2008, 2010) that this amount of pts-component was tolerated in the primary clinopyroxene, albeit metastably, down to relatively low pressures and temperatures, within the field of stability for hornblende ( $\mathrm{P}<2.5 \mathrm{GPa}$, Abbott and Draper, 2008, 2010; Abbott et al., 2006). Introduction of $\mathrm{H}_{2} \mathrm{O}$ then mediated the breakdown of this hypothetical, primary clinopyroxene ( $25 \mathrm{~mol} \% \mathrm{pts})$ to hornblende and the observed secondary clinopyroxene (Abbott and Draper, 2008, 2010).

\subsection{Trace-element mineral chemistry}

The proposed magmatic origin for the garnet-bearing ultramafic rocks depends on a UHP origin for type- 1 and type- 1 ' garnets, and on evidence for the now missing aluminous clinopyroxene. REE data presented here (Fig. 5, Table 2) reveal a UHP signature for both types of garnet, and more interestingly the data reveal the chemical signature of the missing clinopyroxene-precursor to the type- $1^{\prime}$ garnet. Chondrite-normalized (McDonough and Sun, 1995) REEs for all three types of garnet show unusual humped or weakly sinusoidal patterns (upwardly convex), depleted in both heavy REEs and light REEs relative to middle REEs (Fig. 5A, B). None of the garnet shows the expected, typical monotonically positive slope in REEs. All three types of garnet show greater variability in the light REEs than in the heavy REEs, consistent with the former having been affected by late fluid interactions. For both type- ${ }^{\prime}$ ' and type- 1 garnets, the highest $\mathrm{REE}$ ratio is for $\mathrm{Eu}\left(\mathrm{Eu} / \mathrm{Eu}^{*}>1\right.$, where $\left.\mathrm{Eu} / \mathrm{Eu}^{*}=2 \mathrm{Eu} /(\mathrm{Sm}+\mathrm{Gd})\right)$. The REE pattern for the late type- 2 garnet shows an unusual negative $\mathrm{Eu}$ anomaly $\left(\mathrm{Eu} / \mathrm{Eu}^{*}<1\right)$ in an otherwise upwardly convex pattern. REE ratios in clinopyroxene (Fig. 5A, Table 3 ) are similar to those determined for clinopyroxene (Hattori et al., 2010a) in closely related DR garnet-peridotite (assemblage III), and otherwise not unusual.

\section{Discussions}

\subsection{Humped to weakly sinusoidal REE patterns in the garnet}

The humped and weakly sinusoidal (terminology consistent with Banas et al., 2009) REE patterns for garnet from the DR garnet- 

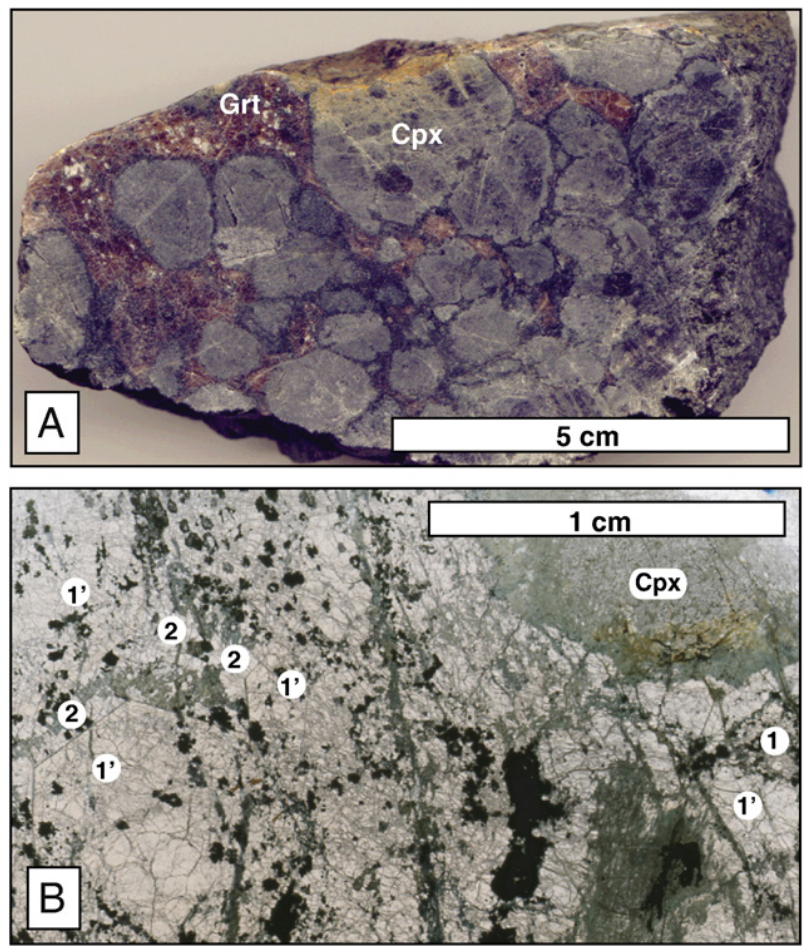

Fig. 3. Photographs of garnet-clinopyroxenite (DR03-12). A. Polished slab of the rock, showing megacrysts of clinopyroxene up to $3 \mathrm{~cm}$ in a matrix of garnet. The clinopyroxene megacrysts are mantled by thin (typically $<1 \mathrm{~mm}$ ) rims of hornblende. The hornblende also fills cracks and fractures in garnet and clinopyroxene, indicating that the hornblende formed after the garnet and clinopyroxene. Microinclusions (typically $<0.1 \mathrm{~mm}$ ) of spinel and corundum occur in garnet but not in clinopyroxene. The white flecks are products of weathering. B. Three types of garnet. Type- 1 garnet (far right) is not associated with clinopyroxene or hornblende. Type- $1^{\prime}$ garnet forms the bulk of the garnet, and is generally not associated with clinopyroxene or hornblende. Locally type- $1^{\prime}$ garnet displays crystal faces (e.g., left side of the image, just above the "B"). Type-2 garnet is associated with hornblende near clinopyroxene and is most conspicuously associated with hornblende as overgrowths on crystal faces of type- $\mathbf{1}^{\prime}$ garnet.

clinopyroxenite (DR03-12) are very unusual (Fig. 5A, B), but similar to REE patterns for garnet in corundum-rich garnetite from the UHP Sulu terrane (Zhang et al., 2004) in China (Fig. 5C). The geochemistry and association of the Sulu garnet suggest crystallization from a melt that originated by partial melting of mantle peridotite (Zhang et al., 2004). For comparison we also show new data on garnet from DR garnet-peridotite (Fig. 5D, Table 3, assemblage III, DR03-10), which is closely related to the garnet-clinopyroxenite(assemblage $\mathrm{V}$ ), and also shows a weakly sinusoidal REE pattern. Garnet inclusions in diamond (Banas et al., 2009; Shimizu and Sobolev, 1995; Stachel et al., 2004) and garnet from kimberlite in South Africa (Hoal et al., 1994) also show humped or sinusoidal REEs, but the highest normalized values are generally shifted towards the light REEs. Humped and sinusoidal REE patterns seem only to occur in garnet from demonstrably UHP mantle environments.

One explanation for garnet with humped or sinusoidal REE patterns involves incomplete equilibration with a late, light REE-enriched metasomatic fluid (Hoal et al., 1994; Zhang et al., 2004). In effect, Stachel et al. (2004) offer the same explanation for "harzburgitic" garnet inclusions in diamond (see also Banas et al., 2009). Fig. 6 illustrates the model, adapted directly from Hoal et al. (1994), wherein the upwardly convex REE patterns resulted from the fluidinteraction with hypothetical precursors (dashed) to the observed type- 1 and type- 1 ' garnets (solid). The light REEs (relatively mobile) for both types of garnet approach equilibrium with a hypothetical metasomatic fluid (Fig. 6) enriched in light REEs, and in this case, possibly arc-related. The heavy REEs (relatively immobile) for both
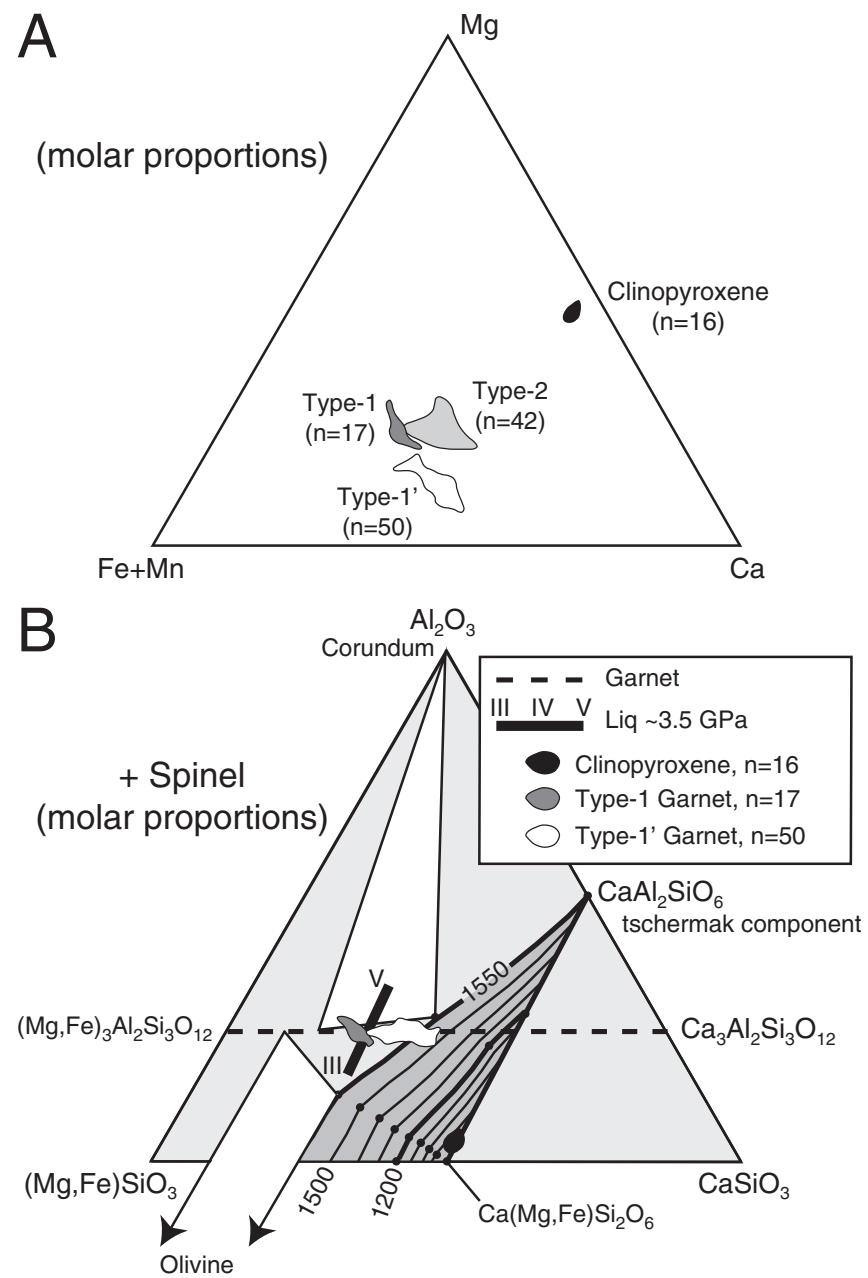

Fig. 4. Chemistry of garnet and clinopyroxene, garnet-clinopyroxenite (DR03-12) A. Molar proportions of $\mathrm{Mg}, \mathrm{Ca}$ and $(\mathrm{Fe}+\mathrm{Mn})$ in the three types of garnet and in clinopyroxene. For each mineral, the number of analyses is indicated in parentheses. B. Chemical analyses of garnet and clinopyroxene superimposed on 3.5-GPa CMAS phase relationships (Abbott and Draper, 2008; Abbott et al., 2005) inferred from 3.0-GPa experimental data (Abbott et al., 2005). Compositions are projected from spinel onto the $\mathrm{Al}_{2} \mathrm{O}_{3}-(\mathrm{Fe}, \mathrm{Mg}) \mathrm{SiO}_{3}-\mathrm{CaSiO}_{3}$ plane. The subsolidus field for clinopyroxene (shaded) contracts dramatically with decreasing temperature, according to the temperature contours. Except for the solidus contour $\left(1550{ }^{\circ} \mathrm{C}\right)$, the contour interval is $100{ }^{\circ} \mathrm{C}$. The temperature-contours are based on 3-GPa experimental data: $1550^{\circ} \mathrm{C}$ CMAS solidus (Abbott et al., 2005), $1200{ }^{\circ} \mathrm{C}$ subsolidus contour (Boyd, 1970), and $\mathrm{CaAl}_{2} \mathrm{SiO}_{6}$ (tschermak clinopyroxene) (Hays, 1966). It is assumed that the clinopyroxene field is not significantly different up to $3.5 \mathrm{GPa}$. Solidus clinopyroxene can be very aluminous, stoichiometrically equivalent to garnet or even more aluminous $\left(1550{ }^{\circ} \mathrm{C}\right)$. The straight bar (with ends marked III and V) is the projected locus of liquids coexisting with garnet + clinopyroxene + spinel (assemblage IV) (Abbott et al., 2005). Type- 1 garnet plots close to the composition of garnet coexisting with liquid + corundum + aluminous clinopyroxene. Type- $1^{\prime}$ garnet plots close to the composition of aluminous clinopyroxene coexisting with liquid + corundum + garnet. Chemical analyses of the observed clinopyroxene plot close to diopside-hedenbergite, within the $900{ }^{\circ} \mathrm{C}$-field for subsolidus clinopyroxene.

types of garnet remain unaffected, by virtue of low diffusivity and reduced gradient in chemical potential. The middle REEs between the highest observed normalized REE value (Eu) and the heaviest REEs preserve varying states of partial equilibrium with the metasomatic fluid. Therefore, the REE values were preserved from the time when the chemical system became close with respect to REE-diffusion or when fluid-flow ceased.

Observations on garnet from South African kimberlites (Hoal et al., 1994) indicate that the final composition of the garnet depends largely on the REE composition of the original garnet. Distinct REE patterns for the type- 1 and type- $1^{\prime}$ garnets also relate to distinct 

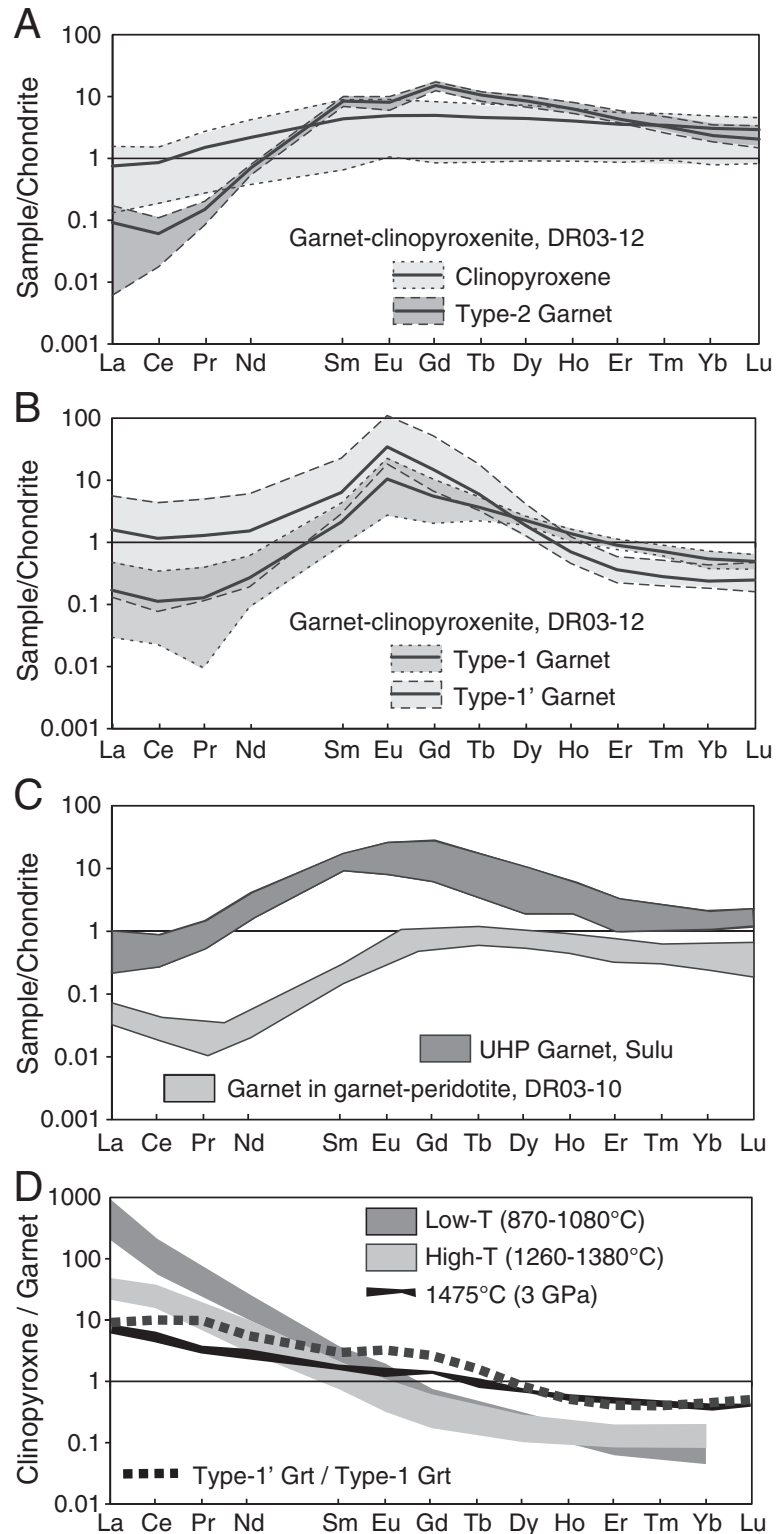

Fig. 5. Chondrite-normalized mineral REE data (Tables 2, 3). A. Clinopyroxene and Type-2 garnet from garnet-clinopyroxenite (DR03-12). For each mineral the average REE values are plotted (bold, solid line); maximum and minimum values bound the shaded region. Note the unusual negative Eu anomaly in the REE ratios for type-2 garnet. B. Type-1 garnet and type- $\mathbf{1}^{\prime}$ garnet from the garnet-clinopyroxenite (DR0312). For each mineral the average REE values are plotted (bold, solid line); maximum and minimum values bound the shaded region. Overlap of the ranges for type- 1 and type-1' garnets appears orange. C. UHP garnet, Sulu terrane, China (Zhang et al., 2004). Also shown are preliminary data for garnet from DR garnet-peridotite (assemblage III, DR03-10), which is closely related to the DR garnet-clinopyroxenite (assemblage V, DR03-12). D. REE partitioning between the average type- $1^{\prime}$ garnet and the average type-1 garnet of the garnet-clinopyroxenite (DR03-12). Shaded regions represent hightemperature $\left(1260-1380^{\circ} \mathrm{C}\right.$ ) and low temperature $\left(960-1080{ }^{\circ} \mathrm{C}\right.$ ) clinopyroxenegarnet REE partitioning from mantle xenoliths (Schmidberger and Francis, 2001). REE partitioning between type- ${ }^{\prime}$ garnet (near isochemically from magmatic high-Al clinopyroxene) and type-1 garnet plots close to experimental data for clinopyroxenegarnet REE partitioning at $1475^{\circ} \mathrm{C}$ (3 GPa) (Tuff and Gibson, 2007).

major-element chemistries of the these garnets, inasmuch as REEpartitioning depends on the major-element chemistry (Hoal et al., 1994). We suggest that a light REE-enriched fluid, very likely arcrelated (Hattori et al., 2010a), was the same fluid responsible for (1) the production of hornblende and type-2 garnet, (2) the variation in light REEs in the type- 1 and type- $1^{\prime}$ garnets, and (3) the metasomatism of clinopyroxene. The very narrow range of heavy REE

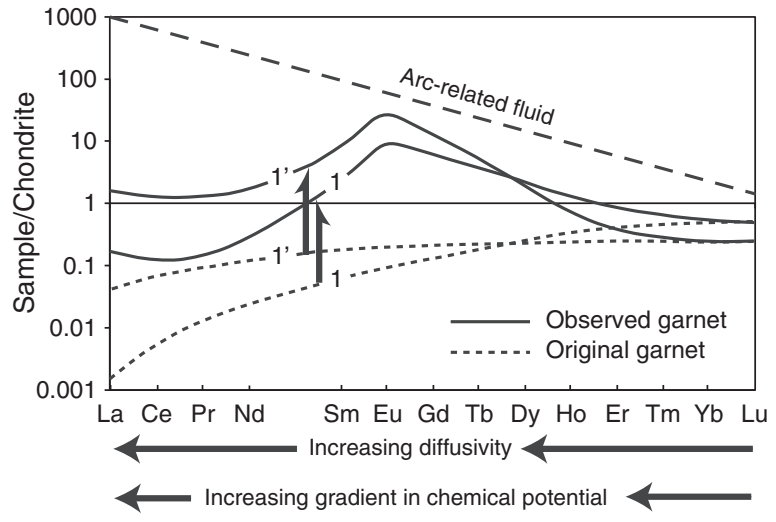

Fig. 6. Model for fluid interaction, modified from Hoal et al. (1994). Observed typeand type- $1^{\prime}$ garnets (Fig. 5B) are illustrated as solid lines; the hypothetical original compositions for the type- 1 and type- $1^{\prime}$ (near isochemically from magmatic high-Al clinopyroxene) garnets are illustrated as dashed lines.

ratios for each of the different types of garnet indicates that the heavy REEs were not significantly affected by the late fluid interaction.

\subsection{REE partitioning}

In mantle rocks the partitioning of REEs between clinopyroxene and garnet $(\mathrm{Cpx} / \mathrm{Grt})$ depends on temperature and atomic number (Schmidberger and Francis, 2001) (Fig. 5D). Element ratios for Cpx/ Grt decrease with increasing temperature for light REEs, and increase with increasing temperature for the heavy REEs. Thus, the negative slope of the partitioning ( $\mathrm{Cpx} / \mathrm{Grt})$ vs. atomic number (Fig. 5D) becomes less steep with increasing temperature. Three-GPa experimental data (Tuff and Gibson, 2007) on clinopyroxene/garnet partitioning at $1475{ }^{\circ} \mathrm{C}$ (Fig. 5D) are consistent with this relationship. Fig. 5D shows that the partitioning of REEs between the average type- $1^{\prime}$ garnet (interpreted as nearly isochemical with magmatic high-Al clinopyroxene, Section 5.2) and the average type- 1 garnet is consistent with clinopyroxene-garnet equilibrium at $\sim 1475^{\circ} \mathrm{C}$ ( $3 \mathrm{GPa}$ ). This partitioning is consistent across the whole spectrum of REEs, strongly supporting the observation that the partitioning of the REEs between the average type- $1^{\prime}$ garnet and average type- 1 garnet was relatively unaffected by the late fluid metasomatism (Fig. 6). Therefore, the REE composition of the average type- 1 garnet is consistent with our interpretation of having equilibrated with a clinopyroxene of a composition now preserved in the type-1' garnet. Assuming this is correct, the gentle negative slope of the REE partitioning suggests a very high equilibrium temperature $\left(\sim 1475^{\circ} \mathrm{C}\right)$, close to the solidus temperature $\sim 1500^{\circ} \mathrm{C}(\mathrm{P}>3.2 \mathrm{GPa}$ ) (Abbott et al., 2005, 2007; Abbott and Draper, also see Appendix A for details).

Also, $\mathrm{Mg}-\mathrm{Fe}$ partitioning between type-1 garnet and spinel suggests high temperatures, $1326{ }^{\circ} \mathrm{C}\left(\mathrm{SD}+/-139^{\circ} \mathrm{C}, \mathrm{n}=6\right)$, in the closely related garnet-peridotite(assemblage III, Abbott and Draper, 2010; Abbott et al., 2007). We therefore infer that the equilibration of REEs between an aluminous clinopyroxene (precursor to the type- $1^{\prime}$ garnet) and type-1 garnet took place during subsolidus cooling, and was largely concluded at a closure-temperature as high as $\sim 1475^{\circ} \mathrm{C}$. The transformation of the hypothetical aluminous clinopyroxene to type- $1^{\prime}$ garnet took place at a lower temperature. Three-GPa experimental data (Boyd, 1970) indicate that type- 1 ' garnet would be stable at $\sim 1200{ }^{\circ} \mathrm{C}$. Type- 2 garnet formed with hornblende during late, low-pressure hydration (Abbott and Draper, 2008, 2010). This late fluid interaction altered the light REEs for both type- 1 garnet and type- 1 ' garnet without significantly affecting the concentrations of the heavy REEs, hence without significantly affecting the partitioning of REEs between the average compositions of the two types of garnet. The REE ratios for the type- 2 garnet possibly reflect available 
reactant minerals (clinopyroxene, type- $1^{\prime}$ and type- 1 garnet) in a system that was open with respect to at least $\mathrm{H}_{2} \mathrm{O}, \mathrm{Na}, \mathrm{Ca}, \mathrm{Mg}$, and Fe (Abbott and Draper, 2010). The negative Eu anomaly in the REE ratios for the type-2 garnet may reflect mobilization of $\mathrm{Eu}(3+)$ under these late, oxidizing conditions. Clinopyroxenes from the garnetclinopyroxenite (assemblage $\mathrm{V}$ ) and the related garnet-peridotite (assemblage III) (Fig. 7 and Table 3) show "spiky" extended traceelement patterns, suggesting that the late fluid interaction was arcrelated. Metasomatism by arc-related fluids produced the expected enrichment of fluid-mobile elements (e.g., $\mathrm{Ba}, \mathrm{U}, \mathrm{Pb}$, and $\mathrm{Sr}$ ) relative to high-field strength elements (e.g., Nb, Ta, and $\mathrm{Zr}$ ) in the clinopyroxenes (Fig.7), affecting also the bulk rock composition.

\subsection{Environment of formation and exhumation}

From a primitive magma composition it is possible to determine the melting conditions. This information is a key to determine the tectonic environment of formation of a magma. For example, melts formed under normal ambient mantle conditions, typical of the midocean ridge system will yield potential temperature $T_{P}$ of $1350 \pm 50{ }^{\circ} \mathrm{C}$ (e.g., Herzberg et al., 2007; McKenzie et al., 2005). On the other hand magmas formed in a restricted thermal anomaly, like a mantle plume, will compute potential temperatures $>1400^{\circ} \mathrm{C}$ (Herzberg and Asimow, 2008; Putirka, 2005). Temperatures calculated from arcderived magmas are generally within ambient mantle estimates $\left(1350-1400^{\circ} \mathrm{C}\right)$, unless there is clear evidence of plume-subduction interaction (see discussion in Gazel et al., 2011).

The very high P-T conditions recorded in the garnet-ultramafic rocks require a magmatic mantle-plume environment. Geodynamic reconstructions (Pindell and Kennan, 2009) and geochemical correlations suggest that the DR garnet-ultramafic rocks may be related to the ancestral Galapagos Plume (Hoernle et al., 2004; Pindell and Kennan, 2009). The very high temperatures reported here are supported by four independent lines of evidence: (1) the intersection of the peridotite solidus and the sapphirine-out reaction (Fig. 2A), (2) phase relationships at P>3.2 GPa (Fig. 4B), (3) garnet-spinel MgFe partitioning (Abbott and Draper, 2010; Abbott et al., 2007), and (4) REE partitioning between the hypothetical magmatic high-Al clinopyroxene (precursor to the type- $1^{\prime}$ garnet)and type- 1 garnet (Fig. 5D). Mantle potential temperatures (1500-1600 ${ }^{\circ} \mathrm{C}$ ) (Herzberg and Gazel, 2009) calculated for Cretaceous (95-80 Ma) plume-related Caribbean lavas are in good agreement with the high temperature recorded in the garnet-ultramafic rocks. Therefore, we suggest that the garnet-ultramafic rocks may represent "fossil" fragments of the mantle plume responsible for the formation of a large part of the Caribbean Plate.

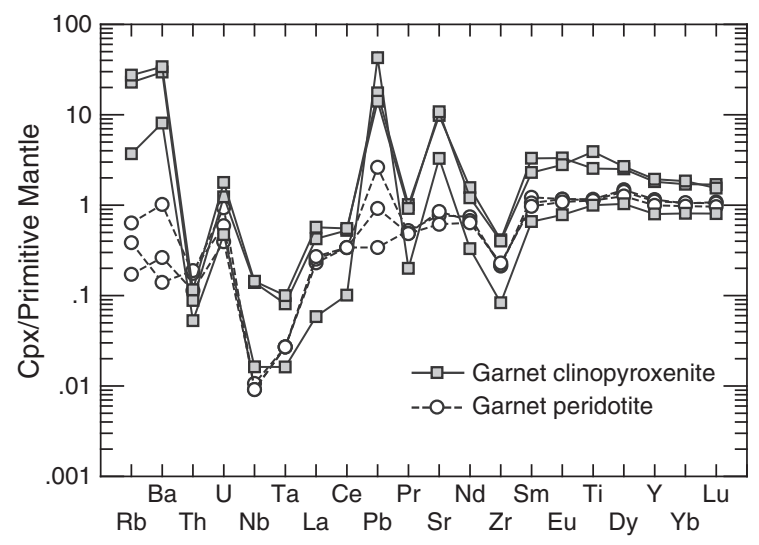

Fig. 7. Pyrolite mantle-normalized (McDonough and Sun, 1995) extended traceelement "spider" diagram for clinopyroxene in garnet-clinopyroxenite (assemblage V) and garnet-peridotite (assemblage III) (Tables 2, 3). The spiky character shows the effect of the late arc-influenced fluid-interaction.
Once formed, the garnet-ultramafic rocks were probably delivered to the subduction zone (Stage 1, Fig. 2B) by forced convection (cornerflow) in the mantle wedge, coupled with erosion of the hanging wall of the mantle wedge. Fragments of the garnet-ultramafic rocks were then incorporated into the eclogite (deep-subducted ocean crust) at the subduction zone. The eclogite, with fragments of garnetultramafic rock onboard, was then uplifted (Stage 2, Fig. 2B) by a still poorly understood mechanism involving reverse flow up the subduction zone (Gerya and Yuen, 2003; Gerya et al., 2002; Gorczyk et al., 2007; Krebs et al., 2008). Final uplift through the crust (Stage 3, Fig. 2B) involved transpressional tectonics.

Our interpretation suggests that an active part of a mantle plume interacted with a subduction zone. Current recontructions of the origin and evolution of the Caribbean Plate (e.g., Hoernle et al., 2004; Pindell and Kennan, 2009) suggest that this type of interaction was possible.

\section{Conclusions}

The Dominican example is the only known UHP garnet-ultramafic suite exhumed at an ocean-ocean convergent plate boundary.

The garnet-ultramafic rocks contain the first reported occurrence of coexisting garnet + spinel + corundum (Abbott et al., 2005; and see Appendix A), indicative of very high pressure.

The humped or sinusoidal REE patterns in the garnet are the second example reported from an orogenic setting (Sulu, China, being the first example, Zhang et al., 2004), and the only example from an oceanic setting. Otherwise, humped and sinusoidal REE patterns for garnet are well known only from garnet inclusions in diamond and garnet in kimberlite.

The petrological and geochemical evidence presented here suggest that these rocks crystallized at $\mathrm{P}>3 \mathrm{GPa}$ and $\mathrm{T}$ approaching $1500^{\circ} \mathrm{C}$ (the highest $\mathrm{T}$ reported in a UHP orogenic setting), providing evidence for an origin in a mantle plume.

\section{Acknowledgements}

The research is supported by National Science Foundation Grants EAR-8306145, EAR-8509542 and INT-0139536 to G.D.; NSF Grants EAR-0111471 and INT-0139490 to R.N.A.; and the Postdoctoral Research Fellowship in Earth, Environmental, and Ocean Sciences from Lamont-Doherty Earth Observatory and the Department of Earth and Enviromental Sciences at Columbia University to E.G. We appreciate the assistance of the CAS Microscope Facility, Appalachian State University, and its director Dr. Guichuan Hou; and technical support of Dr. Louise Bolge during the LA-ICP-MS data collection. The manuscript benefited greatly from comments and suggestions offered by Alan Hastie, Antonio Garcia-Casco, Stacia Gordon, Claude Herzberg, Al Hofmann, Andrew Kerr, Terry Plank, Walter Maresch, Hans-Peter Schertl, Gautam Sen, and Jonathan Snow.

\section{Appendix A}

\section{A1. Magmatic conditions}

Previous estimates of magmatic conditions ( $\mathrm{P}>3.4 \mathrm{GPa}$ and $\mathrm{T}>$ $1550^{\circ} \mathrm{C}$, Abbott et al., 2005, 2007) were based on experimental determinations in two simple systems, relating respectively to the following:

(1) The stability of sapphirine at high pressure. The sapphirine-out reaction $\mathrm{Spr}=\mathrm{Grt}+\mathrm{Spl}+\mathrm{Crn}$ in the MAS system (Ackermand et al., 1975) defines the minimum pressure for the observed assemblage $\mathrm{Grt}+\mathrm{Spl}+\mathrm{Crn}$ in the garnet-clinopyroxenite $(\mathrm{V})$.

(2) The solidus for garnet-peridotite (III) and garnet-clinopyroxenite $(\mathrm{V})$. High pressure ( $3 \mathrm{GPa}$ ) melting experiments in the CMAS 
system (Milholland and Presnall, 1998) show a field of stability for sapphirine, which at higher pressure must disappear where the solidus intersects the sapphirine-out reaction.

The minimum P-T conditions for melt coexisting with Grt + $\mathrm{Spl}+\mathrm{Crn}(+\mathrm{Cpx})$ correspond to the intersection of the garnetclinopyroxenite $(+\mathrm{Spl}+\mathrm{Crn})$ solidus and the sapphirine-out reaction, $\mathrm{Spr}=\mathrm{Grt}+\mathrm{Spl}+\mathrm{Crn}$ (Abbott et al., 2005, 2007). In the CMAS system, the conditions at this intersection are $\mathrm{P} \sim 3.4 \mathrm{GPa}, \mathrm{T} \sim 1550^{\circ} \mathrm{C}$ (open circle in Fig. A1). Thus, the magmatic conditions in CMAS are $\mathrm{P}>3.4 \mathrm{GPa}, \mathrm{T}>1550{ }^{\circ} \mathrm{C}$. Below we explore the effects of other components on the solidus and sapphirine-out reaction.

\section{A1.1. Solidus: garnet-peridotite-garnet-clinopyroxenite}

Non-CMAS components, in particular $\mathrm{Fe}$ and $\mathrm{Na}$, influence the solidus in ways that are difficult to quantify. Milholland and Presnall (1998) argue that addition of $\mathrm{Na}$ and Fe has little effect on the phase relationships and temperature of the solidus in the CMAS system. With regard to $\mathrm{Fe}$, this is corroborated experimentally by Herzberg and coworkers (Herzberg and Zhang, 1997; Herzberg et al., 2000) in detail for equilibria involving combinations of olivine, orthopyroxene, clinopyroxene and garnet, at P $>2.7 \mathrm{GPa}$. Rather than debate the combined effect of non-CMAS components on the temperature of the solidus, the present strategy uses the experimentally determined solidus for natural compositions. Three experimental determinations of the garnet-peridotite solidus are shown in Fig. A1 (Herzberg et al., 2000; Hirschmann, 2000; Walter, 1998). At P $>2.4 \mathrm{GPa}$, the solidus determined by Hirschmann (2000) is slightly lower in temperature than the other two experimental determinations (Herzberg et al., 2000; Walter, 1998). At $3 \mathrm{GPa}$, the Hirschmann (2000) solidus is approximately $50{ }^{\circ} \mathrm{C}$ lower than the haplo garnet-peridotite solidus in the CMAS system (Milholland and Presnall, 1998).

In the garnet-bearing ultramafic rocks from the Dominican Republic, Fe-Mg partitioning between spinel and garnet coexisting

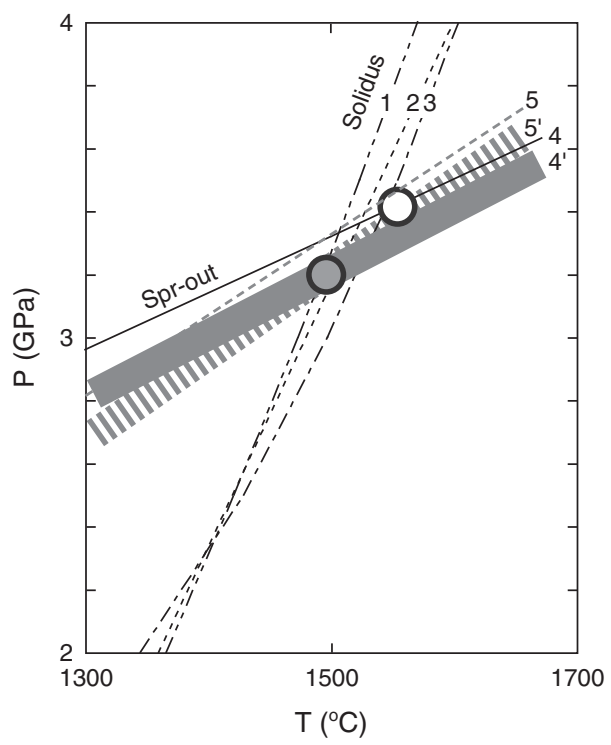

Fig. A1. Minimum P-T conditions for garnet-clinopyroxenite. Previously estimated, minimum P-T conditions (open circle, $\sim 3.4 \mathrm{GPa}, 1550{ }^{\circ} \mathrm{C}$, Abbott et al., 2005) refer to the CMAS system. The new estimate of the minimum P-T conditions (filled circle, 3.2 GPa, $\sim 1500^{\circ} \mathrm{C}$ ) takes into account the effects of non-CMAS components and tschermak substitution. Experimentally determined peridotite solidus: $1=$ Hirschmann (2000), 2 = Walter (1998), 3 = Herzberg et al. (2000). Experimentally determined sapphirineout reaction: 4 (solid line) = MAS system (Ackermand et al., 1975), and 4' (wide, solic band) = adjusted for Mg\# of hypothetical sapphirine coexisting with observed composition of spinel. THERMOCALC results for sapphirine-out reaction: 5 (dashed)= sapphirine of composition $\mathrm{Mg}_{3.5} \mathrm{Al}_{9} \mathrm{Si}_{1.5} \mathrm{O}_{20}$, and $5^{\prime}$ (wide, dashed band)= adjusted for hypothetical Mg\# of sapphirine coexisting with observed composition of spinel. with olivine (Abbott et al., 2007) is consistent with very high temperatures (up to $1500{ }^{\circ} \mathrm{C}$ ), approaching magmatic conditions at $\mathrm{P}>3 \mathrm{GPa}$. By analogy with relationships in the CMAS system (Milholland and Presnall, 1998), the temperature of the solidus for solidus for garnetperidotite (III, $\mathrm{Ol}+\mathrm{Cpx}+\mathrm{Grt}+\mathrm{Spl}$ ), but not by more than $\sim 30{ }^{\circ} \mathrm{C}$ at any pressure (Abbott et al., 2005). For the practical purposes of the present work, the solidus for natural garnet-peridotite, as determined by Hirschmann (2000), offers an adequate representation of the solidus for both the Dominican garnet-peridotite (III, Ol + Cpx + $\mathrm{Grt}+\mathrm{Spl})$ and garnet-clinopyroxenite $(\mathrm{V}, \mathrm{Cpx}+\mathrm{Grt}+\mathrm{Spl}+\mathrm{Crn})$, acknowledging that the solidus for the latter is in fact slightly lower in temperature $\left(<30^{\circ} \mathrm{C}\right.$ lower) than the solidus for the former.

\section{A1.2. Sapphirine-out reaction}

$\mathrm{Fe}^{2+}$ is the most important substituent in sapphirine, and presumably its effect is commensurate with the limited tolerance of sapphirine for that element (in nature $\mathrm{Mg} \#_{\mathrm{Spr}}>75$ and generally $>90$, Ackermand et al., 1975). Variation in Al-content is accommodated by tschermak substitution, $\mathrm{Al}_{2} \mathrm{Mg}_{-1} \mathrm{Si}_{-1}$ (Ackermand et al., 1975; Das et al., 2006). Calculations using THERMOCALC (Holland and Powell, 1998; Powell, 2005; Powell et al., 1998) show that tschermak substitution in sapphirine has little or no effect on the pressure $(\sim 3.1 \mathrm{GPa})$ of the sapphirine-out reaction at $\sim 1400{ }^{\circ} \mathrm{C}$. At higher temperatures, tschermak substitution tends to increase the pressure of the sapphirine-out reaction, but not by more than $\sim 0.2 \mathrm{GPa}$ at $1550^{\circ} \mathrm{C}$. Experimental determination of the sapphirine-out reaction (4, Fig. A1) (Ackermand et al., 1975) is consistent with THERMOCALC estimates for tschermak-substituted sapphirine of composition $\mathrm{Mg}_{3.5}$ $\mathrm{Al}_{9} \mathrm{Si}_{1.5} \mathrm{O}_{20}$ (5, Fig. A1) at $\sim 1500{ }^{\circ} \mathrm{C}(\sim 3.3 \mathrm{GPa})$. At temperatures higher than $\sim 1500^{\circ} \mathrm{C}$, the pressure of the experimentally determined sapphirine-out reaction (Ackermand et al., 1975) is between THERMOCALC results for sapphirine of compositions $\mathrm{Mg}_{4} \mathrm{Al}_{8} \mathrm{Si}_{2} \mathrm{O}_{20}$ (not shown in Fig. A1) and tschermak-substituted $\mathrm{Mg}_{3.5} \mathrm{Al}_{9} \mathrm{Si}_{1.5} \mathrm{O}_{20}$ (5, Fig. A1), but much closer to the sapphirine-out reaction for the latter composition (5, Fig. A1). Other substituents that enter sapphirine in minor amounts (i.e., $\mathrm{Fe}^{3+}$, Be, B, Ca, Cr, and Ti; Podlesskii et al., 2008) raise the pressure of the sapphirine-out reaction (Ackermand et al., 1975; Das et al., 2006). Sapphirine coexisting with Ca-clinopyroxene, presumably saturated with respect to Ca, in 3-GPa melting experiments (Milholland and Presnall, 1998) contains only $0.7 \mathrm{wt} . \% \mathrm{CaO}$ (0.086 Ca per 20-oxygen formula unit).

Of particular interest is the composition of a hypothetical sapphirine that would coexist with the observed compositions of garnet and spinel in the Dominican garnet-peridotite. The composition of sapphirine can be estimated from Fe-Mg partitioning between sapphirine and spinel (Das et al., 2006). Spinel in the Dominican rock ranges from spl ${ }_{64} \mathrm{hc}_{34} \mathrm{mag}_{03}, \mathrm{Mg}_{\mathrm{Spl}} 64$, to $\mathrm{spl}_{43} \mathrm{hc}_{53} \mathrm{mag}_{04}, \mathrm{Mg} \#_{\mathrm{Spl}} 44$ (Abbott et al., 2006). The former composition, $\mathrm{Mg} \#_{\text {Spl }}$ 64, relates to assemblage III $(\mathrm{Ol}+\mathrm{Cpx}+\mathrm{Grt}+\mathrm{Spl})$; the latter, $\mathrm{Mg \#} \#_{\mathrm{Spl}} 44$, relates to the assemblage $\mathrm{V}(\mathrm{Cpx}+\mathrm{Grt}+\mathrm{Spl}+\mathrm{Crn})$. For spinel of $\mathrm{Mg} \#_{\mathrm{Spl}} 64$, coexisting sapphirine would have $\mathrm{Mg} \#_{\mathrm{Spr}} 95$ at $1300{ }^{\circ} \mathrm{C}$ and $\mathrm{Mg} \#_{\mathrm{Spr}}$ 97 at $1500^{\circ} \mathrm{C}$ (Das et al., 2006). For spinel of $\mathrm{Mg} \#_{\mathrm{Spl}} 44$, coexisting sapphirine would have $\mathrm{Mg} \#_{\text {Spr }} 90$ at $1300{ }^{\circ} \mathrm{C}$ and $\mathrm{Mg} \#_{\text {Spr }} 93$ at $1500^{\circ} \mathrm{C}$ (Das et al., 2006).

THERMOCALC (Holland and Powell, 1998; Powell, 2005; Powell et al., 1998) cannot be used directly to calculate the sapphirine-out equilibrium for the hypothetical sapphirine $\left(\mathrm{Mg} \#_{S p r} 90-95,1300{ }^{\circ} \mathrm{C}\right.$; $\mathrm{Mg \#}_{\mathrm{Spr}} 95-97,1500{ }^{\circ} \mathrm{C}$ ) because the relevant composition for the garnet cannot be anticipated independently. However, for tschermaksubstituted sapphirine of composition ( $\mathrm{Fe}, \mathrm{Mg})_{3.5} \mathrm{Al}_{9} \mathrm{Si}_{1.5} \mathrm{O}_{20}$ THERMOCALC does provide data for both $\mathrm{Fe}$ - and $\mathrm{Mg}$-end member sapphirineout reactions. Assuming near ideal Fe-Mg solid-solution (Das et al., 2006), the sapphirine-out reaction for intermediate Mg\#-sapphirine can be linearly estrapolated between the Fe- and Mg-end member reactions. The results of such an exercise are shown in Fig. A1 as the broad, dashed band $\left(5^{\prime}, \mathrm{Mg}_{\mathrm{Spr}} 90-95,1300^{\circ} \mathrm{C}\right.$; $\mathrm{Mg} \#_{\mathrm{Spr}} 95-97$, 
$1500{ }^{\circ} \mathrm{C}$ ), which is displaced relative to the Mg-end member reaction to lower pressure by approximately $0.10-0.20 \mathrm{GPa}$ at $1500{ }^{\circ} \mathrm{C}$. The solid, dark band $\left(4^{\prime}\right)$ in Fig. A1 shows the same magnitude of an effect (i.e., $0.10-0.20 \mathrm{GPa}$ lower $\mathrm{P}$, at $1500{ }^{\circ} \mathrm{C}$ ) applied to the experimentally determined sapphirine-out reaction in MAS (4, Fig. A1) (Ackermand et al., 1975). In the critical region of the solidus, the P-T conditions for the sapphirine-out reactions are essentially the same, whether referred to hypothetical $(\mathrm{Mg}, \mathrm{Fe})_{3.5} \mathrm{Al}_{9} \mathrm{Si}_{1.5} \mathrm{O}_{20}$ (5', Fig. A1) or $\mathrm{Mg}-\mathrm{Fe}$ sapphirine $\left(4^{\prime}\right.$, Fig. A1) extrapolated from experimentally produced Mg-sapphirine (Ackermand et al., 1975). Thus, the intersection of the solidus (garnet-peridotite or garnet-clinopyroxenite) and the sapphirine-out reaction $\left(\mathrm{Mg} \#_{\text {Spr }} 90-95\right.$ at $1300{ }^{\circ} \mathrm{C}$ and $\mathrm{Mg} \#_{\text {Spr }}$ 95-97, $1500{ }^{\circ} \mathrm{C}$ ) is at $\sim 3.2 \mathrm{GPa}, \sim 1500^{\circ} \mathrm{C}$, regardless of the how sapphirine is modeled. For the Dominican garnet-peridotite and garnetclinopyroxenite, the magmatic conditions were therefore $\mathrm{P}>3.2 \mathrm{GPa}$ and $\mathrm{T}>1500{ }^{\circ} \mathrm{C}$. The revised conditions and earlier estimated conditions (Abbott et al., 2005, 2007) are shown in Fig. A1.

\section{A2. Subsolidus P-T conditions: garnet-peridotite}

Average P-T conditions were calculated for the garnet-peridotite (III, Ol $+\mathrm{Grt}+\mathrm{Cpx}+\mathrm{Spl}$ ) using THERMOCALC (Holland and Powell, 1998; Powell, 2005; Powell et al., 1998). Activities of mineral components in garnet (grs, prp, and alm), olivine (fo and fa), and clinopyroxene (di and hd) were calculated using the program $\mathrm{AX}$ (Holland and Powell, 2000). The activities of spl $\left(\mathrm{MgAl}_{2} \mathrm{O}_{4}\right)$ and he $\left(\mathrm{FeAl}_{2} \mathrm{O}_{4}\right)$ were calculated for disordered spinel (Pavese et al., 1999), using the formulations, $a_{\mathrm{spl}}^{\mathrm{Spl}} \sim \mathrm{X}_{\mathrm{Mg}}^{\mathrm{Spl}}(1 / 3)_{\mathrm{Tet}}(2 / 3)_{\text {Oct. }}^{2}$, where $\mathrm{X}_{\mathrm{Mg}}^{\mathrm{Spl}}=\mathrm{Mg} /$ $\left(\mathrm{Mg}+\mathrm{Fe}^{2+}\right)$; and $\mathrm{a}_{\mathrm{hc}}^{\mathrm{Spl}} \sim \mathrm{X}_{\mathrm{Fe}}^{\mathrm{Spl}}(1 / 3)_{\mathrm{Tet}} .(2 / 3)_{\text {Oct. }}^{2}$, where $\mathrm{X}_{\mathrm{Fe}}^{\mathrm{Spl}}=\mathrm{Fe}^{2+} /(\mathrm{Mg}+$ $\left.\mathrm{Fe}^{2+}\right)$. The calculated conditions are $\mathrm{P}=3.4(+/-0.7) \mathrm{GPa}$ and $\mathrm{T}=$ $838(+/-170){ }^{\circ} \mathrm{C}$, where the uncertainty expresses the standard deviation. The conditions (Fig. 2) reflect subsolidus equilibrium, consistent with the presumed pressure of isobaric cooling from magmatic conditions.

\section{References}

Abbott Jr., R.N., Broman, B.N., Draper, G., 2007. UHP magma paragenesis revisited, olivine clinopyroxenite and garnet-bearing ultramafic rocks from the Cuaba Gneiss, Rio San Juan Complex, Dominican Republic. International Geology Review 49, 572-586.

Abbott Jr., R.N., Draper, G., 1998. Retrograde eclogite in the Cuaba Amphibolite of the Rio San Juan Complex, northern Hispaniola. 15th Caribbean Geological Conference (Kingston, Jamaica). Abs

Abbott Jr., R.N., Draper, G., 2007. Petrogenesis of UHP eclogite from the Cuaba Gneiss, Rio San Juan complex, Dominican Republic. International Geology Review 49, 1069-1093.

Abbott Jr., R.N., Draper, G., 2008. Evolution of garnet and clinopyroxene in UHP ultramafic rock, Cuaba Gneiss, Rio San Juan complex, Dominican Republic. Geological Society of America Abstracts with Programs 41 (6), 193-37.

Abbott Jr., R.N., Draper, G., 2010. Comments on "Corundum-bearing peridotite from northern Dominican Republic: a metamorphic product of an arc cumulate in the Caribbean subduction zone," by Hattori et al. (2009). Lithos. doi:10.1016/j.lithos.2010.03.011.

Abbott Jr., R.N., Draper, G., Broman, B.N., 2006. P-T path for ultra high pressure garnet ultramafic rocks of the Cuaba Gneiss, Rio San Juan Complex, Dominican Republic. International Geology Review 48, 778-790.

Abbott Jr., R.N., Draper, G., Keshav, S., 2001. Garnet peridotite found in the Greater Antilles. EOS 82 (35), 381-388.

Abbott Jr., R.N., Draper, G., Keshav, S., 2005. UHP magma paragenesis, garnet peridotite and garnet clinopyroxenite: an example from the Dominican Republic. International Geology Review 47, 233-247.

Ackermand, D., Seifert, F., Schreyer, W., 1975. Instability of sapphirine at high pressures. Contributions to Mineralogy and Petrology 50, 79-92.

Banas, A., Stachel, T., Phillips, D., Shimizu, N., Viljoen, K.S., Harris, J.W., 2009. Ancient metasomatism recorded by ultra-depleted garnet inclusions in diamonds from DeBeers Pool, South Africa. Lithos 112, 736-746.

Boyd, F.R., 1970. Garnet peridotites and the system $\mathrm{CaSiO}_{3}-\mathrm{MgSiO}_{3}-\mathrm{Al}_{2} \mathrm{O}_{3}$. Mineralogical Society of America Special Paper 3, 63-75.

Carswell, D.A., Compagnoni, R., 2003. Introduction with review of the definition, distribution and geotectonic significance of ultrahigh pressure metamorphism. In: Carswell, D.A., Compagnoni, R. (Eds.), Ultrahigh Pressure Metamorphism: European Mineralogical Union Notes in Mineralogy, 5, pp. 3-9.

Carswell, D.A., Zhang, R.Y., 1999. Petrographic characterisitics and metamorphic evolution of ultrahigh-pressure eclogites in plate-collision belts. International Geology Review 41, 781-798.
Cooper, L.B., Plank, T., Arculus, R.J., Hauri, E.H., Hall, P.S., Parman, S.W., 2010. High-Ca boninites from the active Tonga Arc. Journal of Geophysical Research 115, B10206. doi:10.1029/2009JB006367.

Das, K., Fujino, K., Tomioka, N., Miura, H., 2006. Experimental data on Fe and Mg partitioning between coexisting sapphirine and spinel: an empirical geothermometer and its application. European Journal of Mineralogy 18, 49-58.

Draper, G., Gutierrez, G., Lewis, J.F., 1996. Thrust emplacement of the Hispaniola peridotite belt: orogenic expression of the mid-Cretaceous Caribbean arc polarity reversal? Geology 24, 1143-1146.

Draper, G. Mann, P., Lewis, J.F., 1994. Hispaniola, in: Caribbean Geology: Donovan, S.K., Jackson, T.A. (Eds.), An Introduction: University of the West Indies Publishers Association, Kingston, Jamaica ch. 7, 129-150.

Draper, G., Nagle, F., 1991. Geology, structure, and tectonic development of the Rio San Juan Complex, northern Dominican Republic. In: Mann, P., Draper, G., Lewis, J.F. (Eds.), Geologic and Tectonic Development of the North American-Caribbean Plate Boundary in Hispaniola: Geological Society of America Special Paper, 262, pp. 77-95.

Eberle, W., Hirdes, W., Muff, R., Pelaez, M., 1982. The geology of the Cordillera Septentrional (Dominican Republic). In: Snow, W., Gil, N., Llinas, R., RodriguezTorres, R., Tavares, I. (Eds.), Transactions, 9th Caribbean Geological Conference: Santo Domingo, Dominican Republic 1980, pp. 619-632.

Gerya, T.V., Stockert, B., Perchuk, A.L., 2002. Exhumation of high-pressure metamorphic rocks in a subduction channel: a numerical simulation. Tectonics 21 (6-6), 1056. doi:10.1029/2002TC001406.

Gazel, E., Hoernle, K., Carr, M.J., Herzberg, C., Saginor, I., van den Bogaard, P., Hauff, F., Feigenson, M.D., Swisher III, C., 2011. Arc-plume interaction in Central America: influx of Galapagos asthenosphere and slab melting. Lithos 121, 117-134.

Gerya, T.V., Yuen, D.A., 2003. Rayleigh-Taylor instabilities from hydration and melting propel 'cold plumes' at subduction zones. Earth and Planetary Science Letters 212, 47-62.

Gorczyk, W., Guillot, S., Gerya, T.V., Hattori, K., 2007. Asthenospheric upwelling, oceanic slab retreat, and exhumation of UHP mantle rock: insights from the Greater Antilles. Geophysical Research Letters 34, L21309. doi:10.1029/2007GL031059.

Guillot, S., Hattori, K., Agard, P., Schwartz, S., Vidal, O., 2009. Exhumation processes in oceanic and continental subduction contexts: a review. In: Lallemand, S., Funicello, F. (Eds.), Subduction Zone Geodynamics. Springer-Verlag, Berlin, pp. 175-205. doi:10.1007/978-3-540-87974-9.

Hacker, B.R., 2006. Pressure and temperature of ultrahigh-pressure metamorphism: implications for UHP tectonics and $\mathrm{H}_{2} \mathrm{O}$ in subducting slabs. International Geology Review 48, 1053-1066.

Hastie, A.R., Kerr, A.C., 2010. Mantle plume or slab window?: physical and geochemical constraints on the origin of the Caribbean oceanic plateau. Earth-Science Review 98, 283-293.

Hattori, K.H., Guillot, S., Saumur, B.-M., Tubrett, M.N., Vidal, O., Morfin, S., 2010a. Corundum-bearing garnet peridotite from northern Dominican Republic: a product of an arc cumulate in the Caribbean subduction zone. Lithos 114, 437-450.

Hattori, K.H., Guillot, S., Tubrett, M.N., Saumur, B.-M., Vidal, O., Morfin, S., 2010b. Reply to comments by Richard N. Abbott and Grenville Draper. Lithos. doi:10.1016/j. lithos.2010.03.007.

Hays, J.F., 1966. Lime-alumina-silica. Carnegie Institute of Washington Year Book 65, 234-239.

Herzberg, C., Gazel, E., 2009. Petrological evidence of secular cooling in mantle plumes. Nature 458, 619-622.

Herzberg, C., Asimow, P.D., 2008. Petrology of some oceanic island basalts: PRIMELT2. XLS software for primary magma calculation. Geochemistry, Geophysics, Geosystems 9, Q09001. doi:10.1029/2008GC002057.

Herzberg, C., Asimow, P.D., Arnt, N., Niu, Y.L., Lesher, C.M., Fitton, J.G., Cheadle, M.J., Saunders, A.D., 2007. Temperatures in ambient mantle and plumes: constraints from basalts, picrites, and komatiites. Geochemistry, Geophysics, Geosystems 8, Q02006. doi:10.1029/2006GC001390.

Herzberg, C., Raterron, P., Zhang, J., 2000. New experimental observations on the anhydrous solidus for peridotite KLB-1. Geochemistry, Geophysics, Geosystems 1 (10), 1051. doi:10.1029/2000GC000089.

Herzberg, C., Zhang, J., 1997. Melting experiments on komatiite analog compositions at 5 GPa. American Mineralogist 82, 354-367.

Hirschmann, M.M., 2000. Mantle solidus: experimental constraints and effects of peridotite composition. Geochemistry, Geophysics, Geosystems 1 (10), 1042. doi:10.1029/ 2000GC000070.

Hoal, K.E.O., Hoal, B.G., Erlank, A.J., Shimizu, N., 1994. Metasomatism of the mantle lithosphere recorded by rare earth elements in garnets. Earth and Planetary Science Letters 126, 303-313.

Holland, T.J.B., Powell, R., 1998. An internally consistent thermodynamic data set for phases of petrologic interest. Journal of Metamorphic Geology 16, 309-343.

Holland, T.J.B., Powell, R., 2000. AX, Mineral Activity Calculation for Thermobarometry. Cambridge University, Cambridge. computer program AX2 v. 2.2.

Hoernle, K., Hauff, F., van der Bogaard, P., 2004. 70 m.y. history (139-69 Ma) for the Caribbean large igneous province. Geology 32, 697-700.

Jansma, P.E., Mattioli, G.S., Lopez, A., DeMets, C., Dixon, T.H., Mann, P., Calais, E., 2000. Neotectonics of Puerto Rico and the Virgin Islands, northeastern Caribbean, from GPS geodesy. Tectonics 19, 1021-1037.

Kornprobst, J., Piboule, M., Roden, M., Tabit, A., 1990. Corundum-bearing garnet clinopyroxenite at Beni Bousera (Morocco): original plagioclase-rich gabbros recrystallized at depth within the mantle? Contributions to Mineralogy and Petrology 31, 717-745.

Krebs, M., Maresch, W.V., Schertl, H.-P., Munker, C., Baumann, A., Draper, G., Idleman, B., Trapp, E., 2008. The dynamics of intra-ocean subduction zones: a direct comparison 
between fossil petrological evidence (Rio San Juan Complex, Dominican Republic) and numerical simulation. Lithos 103, 106-137.

Kretz, R., 1983. Symbols for rock-forming minerals. American Mineralogist 68, 277-279.

Lewis, J.F., Draper, G., 1990. Geology and tectonic evolution of the northern Caribbean region. In: Dengo, G., Case, J.E. (Eds.), The Caribbean Region. Geological Society of America, Geology of North America H, pp. 77-140.

Liou, J.G., Tsujimori, T., Zhang, R.Y., Katayama, I., Maruyama, S., 2006. Global UHP metamorphism and continental subduction/collision: the Himalayan model. In Liou, J.G., Cloos, M. (Eds.), Phase Relations, High-pressure Terranes, P-T-ometry, and Plate Pushing: Geological Society of America International Book Series, 9, pp. 53-79.

McKenzie, D., Jackson, J., Priestley, K., 2005. Thermal structure of oceanic and continental lithosphere. Earth and Planetary Science Letters 233, 337-349.

Mann, P., Calais, E., Ruegg, J.-C., DeMets, C., Jansma, P.E., Mattioli, G.S., 2002. Oblique collision in the northeastern Caribbean from GPS measurements and geological observations. Tectonics 21, 1057. doi:10.1029/2001TC001304

Mann, P., Schubert, C., Burke, K., 1990. Review of Caribbean neotectonics. In: Dengo, G. Case, J.E. (Eds.), The Caribbean Region. Geological Society of America, Geology of North America H, pp. 307-338.

McDonough, W.F., Sun, S.-S., 1995. The composition of the Earth. Chemical Geology 120 223-253.

Medaris Jr., L.G., 1999. Garnet peridotites in Eurasian high-pressure and ultrahighpressure terranes: a diversity of origins and thermal histories. International Geology Review 41, 799-815.

Milholland, C.S., Presnall, D.C., 1998. Liquidus phase relationships in the system CaO$\mathrm{MgO}-\mathrm{Al}_{2} \mathrm{O}_{3}-\mathrm{SiO}_{2}$ at $3.0 \mathrm{GPa}$ : the aluminous pyroxene thermal divide and highpressure fractionation of picritic and komatiitic magmas. Journal of Petrology 39 $3-27$.

Morishitia, T. Arai, S, Gervilla, F. 2001. High-pressure aluminous mafic rocks from the Ronda peridotite massif, southern Spain: significance of sapphirine- and corundum-bearing mineral assemblages. Lithos 57, 143-161.

Pavese, A., Artioli, G., Russo, U., Hoser, A., 1999. Cation partitioning versus temperature in $\left(\mathrm{Mg}_{0.70} \mathrm{Fe}_{0.23}\right) \mathrm{Al}_{1.97} \mathrm{O}_{4}$ synthetic spinel by in situ neutron powder diffraction. Physics and Chemistry of Minerals 26, 242-250.

Pindell, J.L., Barrett, S.F., 1990. Geological evolution of the Caribbean region; a plate tectonic perspective. In: Dengo, G., Case, J.E. (Eds.), The Caribbean Region. Geological Society of America, Geology of North America H, pp. 405-432.

Pindell, J., Kennan, L., 2009. Tectonic evolution of the Gulf of Mexico, Caribbean and northern South America in the mantle reference frame: an update. In: James, K. Lorente, M.A., Pindell, J. (Eds.), The Geology and Evolution of the Region between North and South America. Geological Society of London Special Publication, pp. $1-60$
Pindell, J., Kennan, L., Maresch, W.V., Stanek, K.-P., Draper, G., Higgs, R., 2005. Platekinematics and crustal dynamics of circum-Caribbean arc-continent interactions and tectonic controls on basin development. In: Avé Lallemant, H.G., Sissons, V.B. (Eds.), Proto-Caribbean Margins, in Caribbean-South American Plate Interactions, Venezuela: Geological Society of America Special Paper, 394, pp. 7-52. doi:10.1130 2005.2394(01).

Podlesskii, K.K., Aranovich, L.Y., Gerya, T.V., Kosyakova, N.A., 2008. Sapphirine-bearing assemblages in the system $\mathrm{MgO}-\mathrm{Al}_{2} \mathrm{O}_{3}-\mathrm{SiO}_{2}$ : a continuing ambiguity. European Journal of Mineralogy 20, 721-734.

Powell, R., 2005. THERMOCALC, (v. tc325)web site: http://www.earthsci.unimelb.edu. $\mathrm{au} / \mathrm{tpg} /$ thermocalc/2005.

Powell, R., Holland, T.J.B., Worley, B.A., 1998. Calculating phase diagrams involving solutions via on-linear equations, with examples using THERMOCALC. Journal of Metamorphic Geology 16, 577-588.

Putirka, K.D. 2005. Mantle potential temperatures at Hawaii, Iceland, and the midocean ridge system, as inferred from olivine phenocrysts: Evidence for thermally driven mantle plumes. Geochemistry Geophysics Geosystems 6, Q05L08. doi:10.1029/2005GC000915.

Schmidberger, S.S., Francis, D., 2001. Constraints on the trace element composition of the Archean mantle root beneath Somerset Island, Arctic Canada. Journal of Petrology 42, 1095-1117.

Shimizu, N., Sobolev, N.V., 1995. Young peridotitic diamonds from the Mir kimberlite pipe. Nature 375, 394-397.

Stachel, T. Aulbach, S., Brey, G.P., Harris, JW, Leost, I., Tappert, R., Viljoen, K.S, 2004 The trace element composition of silicate inclusions in diamond: a review. Lithos $77,1-19$.

Tuff, J., Gibson, S.A., 2007. Trace-element partitioning between garnet, clinopyroxene and Fe-rich picritic melts at 3 to $7 \mathrm{GPa}$. Contributions to Mineralogy and Petrology 153, 369-387. doi:10.1007/s00410-006-0152-x.

Walter, M.J., 1998. Melting of garnet peridotite and the origin of komatiite and depleted lithosphere. Journal of Petrology 39, 29-60.

Whitney, D.L., Evans, B.W., 2010. Abbreviations for names of rock-forming minerals American Mineralogist 95, 185-187.

Zhang, R.Y., Liou, J.G., Zheng, J.P., 2004. Ultrahigh-pressure corundum-rich garnetite in garnet peridotite, Sulu terrane, China. Contributions to Mineralogy and Petrology $147,21-31$.

Zong, K., Liu, Y, Gaoa, C, Hua, Z., Gaoa, S., in press, Garnet-spinel-corundum-quartzbearing titanohematite veins in eclogite from the Sulu ultrahigh-pressure terrane: mprint of a short-lived, high-temperature metamorphic stage. Journal of Asian Earth Sciences, doi:10.1016/j.jseaes.2010.08.003. 